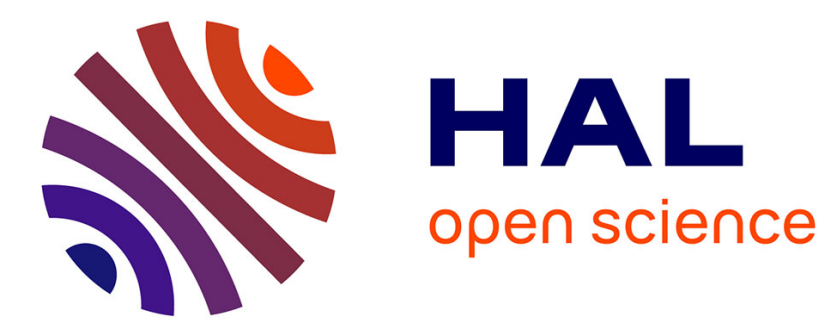

\title{
Multiple environmental tracers for a better understanding of water flux in a wetland area (La Bassée, France) \\ Laurence Gourcy, Agnès Brenot
}

\section{- To cite this version:}

Laurence Gourcy, Agnès Brenot. Multiple environmental tracers for a better understanding of water flux in a wetland area (La Bassée, France). Applied Geochemistry, 2011, 26 (12), pp.2147-2158. 10.1016/j.apgeochem.2011.07.012 . hal-00625695

\section{HAL Id: hal-00625695 https://hal-brgm.archives-ouvertes.fr/hal-00625695}

Submitted on 22 Sep 2011

HAL is a multi-disciplinary open access archive for the deposit and dissemination of scientific research documents, whether they are published or not. The documents may come from teaching and research institutions in France or abroad, or from public or private research centers.
L'archive ouverte pluridisciplinaire HAL, est destinée au dépôt et à la diffusion de documents scientifiques de niveau recherche, publiés ou non, émanant des établissements d'enseignement et de recherche français ou étrangers, des laboratoires publics ou privés. 


\section{Multiple environmental tracers for a better understanding of water flux} in a wetland area (La Bassée, France)

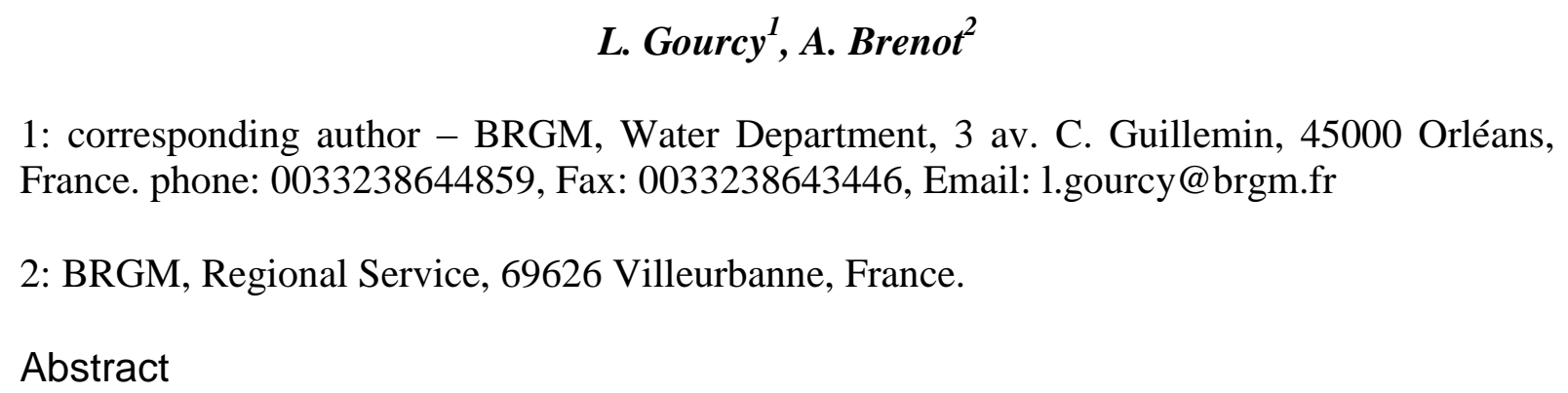

Understanding water exchange between groundwater and streams, or groundwater/surfacewater relationships, is of primary importance for solving conflicts related to water use and for restoring water ecosystems. To this end, we tested a combination of classic geochemical tools and isotopic tools on the Bassée study site, located in the alluvial plain of the River Seine, to see whether they are relevant for tracing multiple and complex groundwater/surface-water relationships. The $\mathrm{Ca} / \mathrm{Sr}$ ratio associated with $\mathrm{Sr}$ isotopes shows contrasted values and suggests that infiltration of surface water to groundwater increases when approaching the Seine. Furthermore, stable isotopes of the water molecule indicate that water from gravel-pit lakes may infiltrate into groundwater. Tritium and CFC tools confirmed surface-water influence on the Alluvial and Chalk aquifers. This geochemical approach, tested on the Bassée site, clearly demonstrates the need of using various geochemical tools for describing groundwater/surface-water relationships, and can be conclusively addressed to other case studies for helping decision makers in their management of natural water resources.

Keywords

$\delta^{18} \mathrm{O}, \delta^{2} \mathrm{H},{ }^{87} \mathrm{Sr} /{ }^{86} \mathrm{Sr},{ }^{3} \mathrm{H}, \mathrm{CFC}, \mathrm{SF}_{6}$, wetland, groundwater, La Bassée, France

\section{INTRODUCTION}

In studies of hydrological systems over the past few years, new environmental tracers have been successfully applied, such as strontium, boron and sulphate isotopes, as well as CFCs and $\mathrm{SF}_{6}$ (e.g. Vengosh et al., 2002; Négrel and Pauwels, 2004; Négrel and Petelet, 2005; Gooddy et al., 2006). New-generation inductively-coupled plasma mass spectrometers (ICPMS) have allowed the development of much more precise isotopic measurements for various elements and a wider use of these tools (e.g. Luais et al., 1997; Marechal et al., 1999; Halicz et al., 1999; Rehkamper and Halliday, 1999; Galy et al., 2001; Rouxel et al., 2002; Beard et 
al., 2003; Cardinal et al.,2003; Wombacher et al., 2003). This has provided larger means of studying hydrological and environmental processes.

Recently, the combined use of various geochemical tracers has been successfully applied for obtaining a better understanding of hydrological systems (Millot et al., 2007; Vengosh et al., 2007; Bouchaou et al., 2009; Ma et al., 2010) as well as of the interaction between groundwater and surface water (Oxtobee and Novakowski, 2002; Lamontagne et al., 2005; Darling et al., 2010). In Millot et al. (2007), the combination of $\mathrm{Li}, \mathrm{B}, \mathrm{Sr}$ and $\mathrm{Nd}$ isotopic systems highlights the complexity of studying geothermal reservoirs, as well as the fact that using only one isotopic tool could lead to an incomplete interpretation of the origin of water. For this reason, the use of a multi-tracer approach is relevant and should provide additional information for the characterization of natural waters in relation to their source.

Langman and Ellis (2009), investigating the source of water, showed the usefulness of a multi-isotope approach in a complex aquifer subject to natural and anthropogenic influences. The use of traditional geochemical tracers commonly is insufficient for explaining the source of water in deeper aquifers and the interactions between aquifers; in this case, additional tools such as $\delta^{11} \mathrm{~B}$ and ${ }^{87} \mathrm{Sr} /{ }^{86} \mathrm{Sr}$ permit a reinterpretation of the isotopic composition of water, leading to a conclusive revision of the hydrological model.

The complementary information these tracers provide, generally confirms the initially established conceptual hydrogeological model. But, in some cases all tracers provide the same information, rendering the use of various tools to be less than cost effective.

Occasionally, the information obtained from various geochemical tracers appears to be contradictory. Though, at first sight, his situation might be considered as a weakness of the multi-tool geochemical approach, it commonly reveals the strength of the method. Understanding a system can initially seem complicated, requiring reappraisal of the initial hypothesis; the use of multiple methods then is the only way of by-passing pre-established hydrogeological models and of proposing new models that consider the full complexity of hydrological systems.

In the present study, we proposed to use various tracers for evaluating the interconnection between aquifers and the possible relationships between surface water and groundwater in a flooded plain. These include tracers of the water cycle $\left(\delta^{2} \mathrm{H}\right.$ and $\left.\delta^{18} \mathrm{O}\right)$, of water-rock interactions $\left({ }^{87} \mathrm{Sr} /{ }^{86} \mathrm{Sr}\right.$ ), of residence time and transfer mode (CFCs and $\mathrm{SF}_{6}$ ), and of anthropogenic impact $\left({ }^{3} \mathrm{H}\right)$.

La Bassée lies south-east of Paris in the alluvial plain of the River Seine. In this area, hydrological flux between surface- and groundwaters is expected to be complex due to the presence of several interconnected aquifers below wetlands, ponds, oxbow lakes, and rivers. The Seine has been channelled since decades and natural flooding is quite reduced in the area. The Bassée site is the last alluvial plain in the Paris Basin exploited for gravel (Baron 
and Piketti, 2001). The intensive sand and gravel extraction throughout the alluvial plain since 40 years has created large borrow-pits that, at the end of the exploitation period, are filled by ground- and rain-water. The Bassée site is also the major wetland area of the lle-deFrance region, labelled 'Natura 2000', and part of a Europe-wide network of sites tasked with the preservation of our natural heritage. It is one of the 87 wetlands of major importance in France and governmental action plans were established in order to protect the surface water covering $20 \%$ of the plain (http://natura2000.environnement.gouv.fr /sites/FR1112002.html). The groundwater here is of great importance as a drinking-water supply and is considered as a reservoir to be protected for the Paris metropolitan-area water supply (SDAGE, Management Plan of Seine-Normandy basin). The study area covers $23 \mathrm{~km}^{2}$ of the downstream part of the alluvial plain. Previous hydrogeological studies (Mégnien, 1965; Sogreah, 2004; Armines, 2005) using classical hydrogeological investigation methods (water-level monitoring, geology, geophysics, geotechnics, and modelling) left uncertainties on the magnitude of the relations between deep and alluvial aquifers, on the possible hydraulic connections between deep aquifers and the river, and on the extent of the relationships between the River Seine and shallow aquifers.

The scope of this study was to improve the hydrological understanding of the system through the use of multiple geochemical tools, in order to arrive at a better protection of this floodplain from qualitative and quantitative points of view. To this end, three different types of water relationships had to be evaluated in the alluvial plain: Chalk and Alluvial groundwater connections, groundwater (Chalk and Alluvial) and river water relationships, and the relation between other surface waters (oxbow lakes, ponds, gravel pit lakes) and groundwater. The alluvial plain in the past having been subject to periodic flooding by the Seine and today being intensively exploited for sand and gravel extraction, the existing surface water is of particular ecological and hydrological importance in the studied area.

\section{CHARACTERISTICS OF THE BASSÉE SITE}

The Bassée site, south-east of Paris, is of major importance for the drinking-water supply of Paris and surroundings. The site lies in the large Seine floodplain, delimited upstream by Bray-sur-Seine and to the west by the Montereau-Fault-Yonne at the junction between the rivers Seine and Yonne (Fig. 1). In view of its numerous ponds, canals and river arms, the Bassée plain was included in the "Natura 2000" program.

Sand and gravel exploitation and agriculture are the main economic activities in the area. Three aquifers are interconnected: i) the Alluvial aquifer of the River Seine located within the whole studied area, ii) the mainly unconfined Chalk aquifer below the alluvial one, and iii) the Tertiary calcareous formations in the northern part of the area (Fig. 2). The Alluvial and Chalk aquifers discharge into the Seine (Weng et al., 1999; Vernoux et al., 2004). Groundwater 
114 within the Alluvial aquifer circulates following the Seine-flow direction, while groundwater flow

115 in the Chalk aquifer is south-east to north-west. This geometry induces most probably a

116 connection between the Chalk and Alluvial aquifers, with direct or indirect (by drainage) flow

117 of the Chalk aquifer into the Alluvial layers. The very low regional slope created various

118 meanders that have led to an important and heterogeneous Alluvial aquifer. The water-level

119 map (Mégnien, 1965) indicates hydraulic continuity between these two aquifers. The Chalk

120 aquifer is considered as a major component of Alluvial aquifer recharge.

121 In the northern part of the study area, the chalk formations are becoming less permeable and

122 the groundwater is sometimes in semi-oxic or anoxic conditions. The Tertiary aquifer is

123 located only in the northern part of the Seine floodplain and is a multilayer calcareous and

124 marly calcareous aquifer, which locally may recharge the alluvial layers. Thus, recharge of

125 the Alluvial aquifer occurs directly from precipitation, or through the other aquifers of the

126 studied site. Natural Seine channels and spaces left by sand and gravel pits form numerous

127 overflowing areas. During high-water periods, river water infiltration may be possible.

128 It is estimated that about 100 lakes were formed by sand and gravel extraction in the lowest

129 part of the Bassée plain. After closure of the gravel pits, the space left is filled with low-

130 permeability material such as clay and silt from recent alluvial deposits, and rapidly reaches

131 equilibrium with the Alluvial and Chalk groundwater. These gravel-pit lakes are believed to

132 have very low surface-groundwater exchanges (Schanen et al., 1998).

\section{3. MATERIAL AND METHODS}

\section{$134 \quad 3.1$ Sampling procedures}

135 Two sampling campaigns were carried out in June 2007 during the high water period and in

136 November 2007 during a low water period. Sampled were 7 locations in the Chalk (noted

137 Sc), and 12 locations in the alluvial aquifers (noted Sa), the Seine upstream at Bray-sur-

138 Seine and downstream just before the confluence of the Rivers Seine and Yonne. Sampling

139 was realised using 6" piezometers drilled in 2002. The complete technical description (total

140 depth, depth to groundwater, lithology, depth to screens,....) is available and allowed to

141 select only the piezometers exploiting a unic geological formation (Chalk or Alluvial). In

142 addition, two gravel-pit lakes at La Tombe and Bazoches-lès-Bray and a well located at La-

143 Chapelle-sur-Oreuse in the Chalk aquifer upstream from the Bassée alluvial plain were

144 sampled in November 2007 (Fig. 1). A complementary sampling campaign tooks place in

145 July 2008. Tritium analyses were carried out on water of all groundwater points sampled in

1462007 and the Seine at Bray-sur-Seine.

147 The analyses of major chemical elements and stable water isotopes $\left(\delta^{2} \mathrm{H}, \delta^{18} \mathrm{O}\right),{ }^{3} \mathrm{H}$,

$148{ }^{87} \mathrm{Sr} /{ }^{86} \mathrm{Sr}$, were completed by the determination of apparent groundwater ages using CFCs 
and $\mathrm{SF}_{6}$.

150 The boreholes were sampled after pumping at least three purge volumes and stabilizing the

151 chemical groundwater parameters, such as $\mathrm{pH}$ and conductivity. Samples for cation and

$152{ }^{87} \mathrm{Sr} /{ }^{86} \mathrm{Sr}$ determinations were kept in polyethylene bottles after acidification with nitric acid.

153 Raw water samples of $50 \mathrm{ml}$ and 1 litre in HDPE bottles were used for $\delta^{2} \mathrm{H}, \delta^{18} \mathrm{O}$ and ${ }^{3} \mathrm{H}$ 154 analyses. Glass sampling bottles of $500 \mathrm{ml}$ were used for CFC and $\mathrm{SF}_{6}$ analyses (IAEA, 155 2006).

\section{3.2. Analytical methods}

157 Concentrations were measured on water samples by inductively coupled plasma-atomic 158 emission spectrometry (ICP-AES) for $\mathrm{Ca}^{2+}, \mathrm{Na}^{+}, \mathrm{K}^{+}$and $\mathrm{Mg}^{2+}$, and by ion chromatography for $159 \mathrm{Cl}^{-}, \mathrm{NO}_{3}{ }^{-}, \mathrm{SO}_{4}{ }^{2-}$ and $\mathrm{PO}_{4}{ }^{2-}$ (uncertainty for both methods 5-10\%). Anion analyses were done 160 by ion chromatography (model DX120, Dionex®), cations by Inductively Coupled Plasma 161 Atomic Emission Spectroscopy (ICP-AES; Ultima-2 model, Jobin Yvon®). The accuracy of 162 both techniques was around 5-10\% depending upon the concentration.

163 Sr concentrations were measured by inductively coupled plasma mass spectrometry (ICP. $164 \mathrm{MS}$ ) (uncertainty 5\%). Alkalinity was determined by $\mathrm{HCl}$ titration and Gran's method. 165 Strontium for isotopic analysis was separated using an ion-exchange column (Sr-Spec resin). 166 Procedural blank levels were lower than $0.5 \mathrm{ng}$. The ${ }^{87} \mathrm{Sr} /{ }^{86} \mathrm{Sr}$ ratio was measured using a 167 Finnigan MAT 262 multiple collector mass spectrometer. Sr isotopic ratios were normalized 168 to ${ }^{87} \mathrm{Sr} /{ }^{86} \mathrm{Sr}=0.1194$. Average uncertainties on individual ${ }^{87} \mathrm{Sr} /{ }^{86} \mathrm{Sr}$ measurements were $8.10^{-6}$ 169 (at $2 \sigma$ level). International reference NIST-NBS987 measurements yielded ${ }^{87} \mathrm{Sr} /{ }^{86} \mathrm{Sr}=$ $1700.710238 \pm 22(2 \sigma ; \mathrm{N}=18)$. Isotopic ratios of both $\mathrm{O}$ and $\mathrm{H}$ are given in per mil $(\%)$ versus 171 VSMOW (Vienna Standard Mean Ocean Water) reference material in the usual $\delta$-scale 172 defined as $\left.\left.\delta_{\text {sample }} \%\right)=\left\{\left(\mathrm{R}_{\text {sample }} / \mathrm{R}_{\text {standard }}\right)-1\right)\right\}^{*} 1000$, where $\mathrm{R}$ is the ${ }^{2} \mathrm{H} /{ }^{1} \mathrm{H}$ and ${ }^{18} \mathrm{O} /{ }^{16} \mathrm{O}$ atomic 173 ratios. $\mathrm{O}$ and $\mathrm{H}$ isotopic composition of water was measured with a Finnigan MAT 252 mass 174 spectrometer with an uncertainty of $\pm 0.1 \%$ and $\pm 0.8 \%$ for $\delta^{18} \mathrm{O}$ and $\delta^{2} \mathrm{H}$, respectively.

175 Samples for tritium activity measurements were collected in one litre polyethylene bottles. 176 Analyses were done by direct liquid scintillation counting. The detection limit was 10 TU 177 (Tritium Unit with $1 \mathrm{TU}$ equal to 1 tritium atom in $10^{18}$ hydrogen atoms). All isotopic analyses 178 were carried out by the BRGM Geochemistry Laboratory.

179 Samples for $\mathrm{CFC}$ and $\mathrm{SF}_{6}$ were collected in $500 \mathrm{~mL}$ glass bottles. To avoid any air 180 contamination, each bottle was kept in a water-filled metal box. A simplified sample collection 181 method described by IAEA (2006) was applied. The analyses were performed by gas 182 chromatography with an electron-capture detector after pre-concentration using the purge183 and-trap technique developed by Spurenstofflabor, Wachenheim (Germany). The detection 184 limit was close to $10^{-4} \mathrm{pmol}$, allowing the measurement of CFC concentrations down to 
$1850.01 \mathrm{pmol} \mathrm{L}^{-1}$ and $\mathrm{SF}_{6}$ concentrations to $0.1 \mathrm{fmol} \mathrm{L}^{-1}$. The reproducibility was about $\pm 5 \%$ for 186 water samples.

\section{4. RESULTS}

\section{$188 \quad 4.1$ Chemical composition of groundwater}

189 Physico-chemical parameters (Table 1) indicate that groundwater conditions in the northern 190 part of the studied area, on the right bank of the Seine, are mainly semi-oxic. Eh is $<200 \mathrm{mV}$ $191 \mathrm{NHE}$ (normal hydrogen electrod) for six wells in the Alluvial and Chalk aquifers. In addition, 192 the $\mathrm{NO}_{3}$ concentration below the detection limit indicating possible denitrification for various 193 points compatible with semi-oxic conditions observed in part of the aquifer. Surface- and 194 groundwaters are of the $\mathrm{Ca}-\mathrm{HCO}_{3}$ type (Fig. 3). Water from one well, Sa26, is of the $\mathrm{Ca}-\mathrm{SO}_{4}$ 195 type. Water in well $\mathrm{Sc13}$ has very low $\mathrm{SO}_{4}$ concentrations, representing the more anoxic 196 conditions and possible sulphate reduction.

197 Binary diagrams (Fig. 4a) confirm an excess of sulphate compared to chloride from rainfall 198 origin. All surface- and groundwaters fall above the theoretical dilution line for sea water. 199 Sulphate may originates from evaporates, but another possible source is gypsum for soil 200 improvement, or fertilizers. In Figure 4b some points are also clearly enriched in chloride 201 compared to sodium ions. As local rocks are evaporite free, potential chloride sources are rainfall and Manmade ones. Around Paris, $\mathrm{Cl}$ concentrations in precipitation are close to $0.15 \mathrm{~mol} / \mathrm{L}$ (Mégnien, 1979). Considering an average enrichment factor (F) estimated by Rainfall $_{(\mathrm{mm}}$ yearly average $)\left(\mathrm{R}\right.$-Evapotranspiration $\operatorname{process}_{(\mathrm{mm}}$ yearly average $)$ of 1.5 , chloride concentrations up to $0.23 \mathrm{mmol} / \mathrm{L}$ are from rainfall origin.

The anthropogenic impact on surface- and groundwater is important in the Bassée plain where agriculture is the main economical activity, even if gravel extraction gains on cultivated lands. On a $\mathrm{NO}_{3}$ vs. Cl diagram (Fig. 5) both groundwater from shallow (Alluvial) and deep (Chalk) aquifers present nitrate concentrations over $25 \mathrm{mg} / \mathrm{L}(0.4 \mathrm{mmol} / \mathrm{L})$ and up to $83.1 \mathrm{mg} / \mathrm{L}$ (1.34 mmol/L; Sa21). Nitrate concentrations below the detection limit of $0.5 \mathrm{mg} / \mathrm{L}$ and chloride contents over $0.23 \mathrm{mmol}$ indicate possible denitrification processes for these waters in wells Sa26, Sc09, Sc13, Sc16, SC22, ScH4, Sa16 and Sa38 (only for the November campaign). In addition, the gravel-pit lakes have very low nitrate concentrations ( $<0.5$ and $2.8 \mathrm{mg} / \mathrm{L}$ or $<0.01$ and $0.05 \mathrm{mmol} / \mathrm{L}$ ).

215 Intense pressure from agriculture is also reflected in groundwater by the presence of four 216 pesticides in 116 analysed samples, which were detected at concentrations above the 217 detection limits. These pesticides and degradation molecules are atrazine (max. $0.091 \mathrm{mg} / \mathrm{L}$ 218 in the Voulzie River), deethylatrazine (max. $0.3 \mathrm{mg} / \mathrm{L}$ in Sc09), glyphosate (max. $5.59 \mathrm{mg} / \mathrm{L}$ in 219 Sa37) and aminomethylphosphonic acid, AMPA (max. $2.52 \mathrm{mg} / \mathrm{L}$ in Sa21). Atrazine has not been used in this area since 2003. Glyphosate has both agricultural and non agricultural 221 uses, which makes its origin difficult to identify. 
Both $x$ vs. y and Piper diagrams highlight a similar chemistry for both Alluvial and Chalk groundwaters. In addition, the chemistry of the Seine and Voulzie is not very different from

224 that of groundwater.

\subsection{Strontium isotopes}

In the Bassée flood plain area, $\mathrm{Ca}$ vs. Sr shows a good correlation whereas the $\mathrm{NO}_{3} v s$. $\mathrm{Sr}$ correlation is weak, indicating a dominant lithological origin for $\mathrm{Sr}$ (Figs. 6a and 6b). Sr and the ${ }^{87} \mathrm{Sr} /{ }^{86} \mathrm{Sr}$ ratio may therefore be controlled only by water-rock interaction in the Bassée flood plain, as anthropogenic input of $\mathrm{Sr}$ can be neglected.

231 The strontium-isotope range observed in this study agrees with values expected for Jurassic carbonate rock $\left({ }^{87} \mathrm{Sr} /{ }^{86} \mathrm{Sr}=0.7067\right.$ to 0.7078$)$ and Cretaceous Chalk $\left({ }^{87} \mathrm{Sr} /{ }^{86} \mathrm{Sr}=0.7072\right.$ to 0.7080) (Koepnick et al., 1985, 1990). Furthermore, values measured in this study for the Chalk aquifer are compatible with those acquired by Négrel and Petelet-Giraud (2005) for this aquifer in the Somme Basin, north of Paris. Nevertheless, values measured in this study are globally higher than those documented in the previously cited article. This result implies the contribution of other $\mathrm{Sr}$ sources in addition to carbonate dissolution. The hypothesis of a strontium contribution from anthropogenic origin was rejected because of the low $\mathrm{Sr}$ concentrations observed $(<8 \mu \mathrm{mol} / \mathrm{L})$ and the lack of significant correlation between $\mathrm{Sr}$ concentrations and nitrate (Fig. 6b) or chloride concentrations (not shown here). On a ${ }^{87} \mathrm{Sr} /{ }^{86} \mathrm{Sr}$ vs. 1/Sr (Fig. 7a) diagram, samples plot globally in a triangle. In this classic diagram, such a distribution suggests that, at least, three sources of dissolved $\mathrm{Sr}$ must explain the ground- and surface-water composition. One end-member should display low ${ }^{87} \mathrm{Sr} /{ }^{86} \mathrm{Sr}$ values and high $\mathrm{Sr}$ concentrations (End-member 1). Another end-member is expected to have high ${ }^{87} \mathrm{Sr} /{ }^{86} \mathrm{Sr}$ values and intermediate $\mathrm{Sr}$ concentrations (End-member 2). A third endmember would display low ${ }^{87} \mathrm{Sr} /{ }^{86} \mathrm{Sr}$ values and low $\mathrm{Sr}$ concentrations (End-member 3). Endmember 1 displays a Sr concentration and Sr-isotope composition close to the composition of the Sa26 sampling point $\left({ }^{87} \mathrm{Sr} /{ }^{86} \mathrm{Sr}=0.70792\right.$ and $0.70796 ; 7.51$ and $\left.7.19 \mu \mathrm{mol} / \mathrm{L}\right)$ and compatible with a Sr contribution from carbonate dissolution. End-member 2 is close to the Sc22 and Sa37 sampling points, both of which display the highest ${ }^{87} \mathrm{Sr} /{ }^{86} \mathrm{Sr}$ and $\mathrm{Ca} / \mathrm{Sr}$ ratios measured in this study (Fig. 8). The $\mathrm{Ca} / \mathrm{Sr}$ ratio was demonstrated elsewhere to be a good tool for tracing contrasting lithological origins (Brenot et al., 2008). As there is no correlation between ${ }^{87} \mathrm{Sr} /{ }^{86} \mathrm{Sr}$ (or for the $\mathrm{Ca} / \mathrm{Sr}$ ratio) and the $\mathrm{NO}_{3}$ concentration (index of anthropogenic origin), End-member 2 most probably has a lithological origin. Nevertheless, the ${ }^{87} \mathrm{Sr} /{ }^{86} \mathrm{Sr}$ and $\mathrm{Ca} / \mathrm{Sr}$ ratios measured for the Sc22 and Sa37 sampling points (defining End-member 2) are much higher than expected values for local carbonate rock (as discussed above). A similar deviation towards a radiogenic composition (higher ${ }^{87} \mathrm{Sr} /{ }^{86} \mathrm{Sr}$ values) was earlier observed locally in the Seine Basin (Roy et al., 1999; Brenot et al., 2008), and for the Chalk aquifer in 
the Somme Basin (Négrel and Petelet-Giraud, 2005). In these cases, the authors suggested

260 that radiogenic $\mathrm{Sr}$ might derive in part by thin marly-clayey beds in carbonate rock through 261 ion exchange or desorption of $\mathrm{Sr}$, or by dissolution of the potential dolomitic part of carbonate 262 rock with a more radiogenic isotopic signature. End-member 3 is close to the composition of 263 Seine water, water from gravel-pit lakes and the Sa48 and Sc13 sampling points. 264 Furthermore, the Sr-isotope composition of Seine water (Roy, 1996) falls between 0.70777 265 and 0.70793 , close to the composition expected for End-member 3. Thus, End-member 3 266 could potentially reflect a contribution of dissolved elements in surface water. Water in the 267 Voulzie River has a different Sr isotopic signature compared to that of the Seine (Fig. 7) and 268 water from gravel-pit lakes, which could be explained by significant differences in water-rock 269 interaction. Indeed, the Voulzie River flows through Early Tertiary layers composed of clay 270 and organic matter, whereas the Seine above the Bassée floodplain mainly flows over 271 carbonate rock (Roy et al., 1999). The Chalk aquifer sampled upstream also has a quite 272 different Sr-isotope signature compared to the Chalk aquifer sampled in the Bassée 273 floodplain (Fig. 7).

274 On a ${ }^{87} \mathrm{Sr} /{ }^{86} \mathrm{Sr}$ vs. Ca/Sr diagram (Fig. 7b), a positive correlation is seen between ${ }^{87} \mathrm{Sr} /{ }^{86} \mathrm{Sr}$ 275 values and the $\mathrm{Ca} / \mathrm{Sr}$ ratio for all sampling points. The lowest Sr-isotope composition and $\mathrm{Ca} / \mathrm{Sr}$ ratio in this study are in the Seine $\left({ }^{87} \mathrm{Sr} /{ }^{86} \mathrm{Sr}=0.70793\right.$ to 0.70778 ; $\mathrm{Ca} / \mathrm{Sr}=424$ to 964$)$, whereas the highest Sr-isotope compositions and $\mathrm{Ca} / \mathrm{Sr}$ ratios occur in groundwater at the Sc22 and Sa37 sampling points $\left({ }^{87} \mathrm{Sr} /{ }^{86} \mathrm{Sr}=0.70832\right.$ to $0.70858 ; \mathrm{Ca} / \mathrm{Sr}=1103$ to 1253$)$.

Based on only ${ }^{87} \mathrm{Sr} /{ }^{86} \mathrm{Sr}$ values, and $1 / \mathrm{Sr}$ and $\mathrm{Ca} / \mathrm{Sr}$ ratios (Fig. 7), one cannot discriminate the groundwaters of the Alluvial and Chalk aquifers sampled in the Bassée floodplain.

\subsection{Tritium and CFC data}

The trends of CFCs and $\mathrm{SF}_{6}$ used as input functions in air correspond to those of the Mace Head (Ireland) station from the ALE/GAGE/AGAGE program (available from cdiac.esd.ornl.gov/ftp/ale_gage_Agage/; Prinn et al., 2000), the closest survey station to the Bassée site. Apparent groundwater ages were evaluated by using Excel® programs for CFC developed by the International Atomic Energy Agency (IAEA, 2006). The recharge date was determined by comparing the calculated partial pressure of $\mathrm{CFCs}$ and $\mathrm{SF}_{6}$ in solubility equilibrium with the water sample, with historical CFC concentrations in local air. The equilibrium concentration of CFCs in groundwater depends on the air pressure (i.e. altitude) and temperature in the saturated zone. Recharge temperatures used are the temperature of groundwater at high-water-stage sampling time. The mean altitude of recharge is close to $55 \mathrm{~m}$, the average altitude of the alluvial plain. The uncertainty in recharge temperatures and recharge elevations is respectively maximum $1^{\circ} \mathrm{C}$ and 50 meters. CFC-11, CFC-12, CFC-113, and $\mathrm{SF}_{6}$ were systematically measured for groundwater dating. For five sampling points, Sa26, Sa38, Sa48, Sc16 and ScH4, semi-anoxic conditions most 
296 probably caused a degradation of CFCs (Horneman et al., 2008), in which case $\mathrm{SF}_{6}$ was

297 then used for dating the water, this element being less sensitive to microbial degradation.

298 All water samples could be dated at least once. Determination of apparent water ages using 299 CFC and $\mathrm{SF}_{6}$ (Plummer and Busenberg, 2000) was done by applying a binary mixing model 300 considering old water before 1950 (CFC-free) and young water with an age between 1985 301 and Present. This model was given the best results in "age-dating" (example for CFC-11 and 302 CFC-113 given in Fig.8). Young-water mixing fractions ranged from 0.20 to 0.99 . Results 303 from the two sampling campaigns are quite similar. The uncertainty in recharge temperature 304 estimation (about $1^{\circ} \mathrm{C}$ what is the annual variability of groundwater temperature) is leading to 305 an uncertainty in mixing ratio of a maximum of $5 \%$. Anthropogenic contamination was 306 observed in few samples, mainly for CFC-12 and $\mathrm{SF}_{6}$ possibly due to the proximity of large 307 urban areas (Oster et al., 1996; Santella et al., 2008).

308 The dissolved gases and age-dating interpretation show a significant differentiation between 309 the Chalk and Alluvial aquifers. Only two wells (<20\%) located in the Alluvial aquifer (Sa5, 310 Sa20) have a percentage of young water below or equal to $50 \%$, whereas five deep wells 311 (>71\%) tapping the Chalk aquifer (Sc11, Sc16, Sc22, ScH3, ScH4) show a percentage of 312 young water below 50\%. Surprisingly, wells Sc13 and Sc09 in the Chalk aquifer mainly 313 contain young water, and a direct influence of surface water on these points is expected. 314 Being far from the River Seine, the influence of ponds or gravel-pit lakes is supposed. The 315 Alluvial groundwater in $75 \%$ of the wells is represented by water with a present $(1985-2007)$ 316 component below $80 \%$. Therefore, the older and deeper groundwater component is 317 significant, confirming the initial conceptual hydrogeological model of the Chalk aquifer 318 discharging into the upper aquifer layers.

319 A few kilometres upstream from the Bassée floodplain, the nuclear power plant at Nogent320 sur-Seine regularly has released tritium into the Seine since its start-up in 1988-1989. Tritium 321 can thus be used as a radionuclide tracer (Sanchez-Cabeza and Pujol, 1999) of the 322 infiltration of the Seine to groundwater since then. In the Seine at Bray-sur-Seine, the tritium 323 concentration measured during the project is quite variable, from $21 \mathrm{TU}$ in July 2008 up to $324573 \mathrm{TU}$ in April 2008, reflecting the variable release from the power plant (3.1 to $32511.7 \mathrm{TBq} /$ month for the period August 2006-August 2008, data provided by EDF, the 326 operator). By comparison, the tritium values for Orléans precipitation (closest station at about $327120 \mathrm{~km}$ from the Bassée site) have on average below 6 TU since 1999 (IAEA/WMO, 2009).

328 Tritium values measured in groundwater are very high (>60 TU) for Sc13, Sa41, Sa48 and 329 Sa61, and high (>15 TU) for Sc09, indicating a more or less important influence of surface 330 water on the Chalk and Alluvial aquifers at these points.

\section{4.4. Stable isotopes}


332 The $\delta^{2} \mathrm{H}$ and $\delta^{18} \mathrm{O}$ isotope composition of groundwater is -47 to $-25 \%$ and -7.1 to $-2.4 \%$, 333 respectively (Table 1 ). In the $\delta^{2} \mathrm{H}$ vs. $\delta^{18} \mathrm{O}$ diagram (Fig. 9), most of the water falls on the 334 local meteorological line (LML) represented by Orléans station (IAEA/WMO, 2009) with no 335 significant difference between the Alluvial and Chalk aquifers and the River Seine. The 336 average annual composition of $\delta^{2} \mathrm{H}$ and $\delta^{18} \mathrm{O}$ of the Seine water measured from oct.74 to 337 sep.76 at Poses (upstream Paris, $200 \mathrm{~km}$ far from La Bassée; Conrad et al., 1978) is falling 338 very closed to the 1996-2010 weighted mean of precipitation collected at Orléans.

339 The most isotopically depleted groundwater is that sampled in the Chalk aquifer upstream 340 from the Bassée area, which thus can be considered as the Chalk aquifer without influence 341 by surface and/or alluvial water. Another groundwater sample taken in 2009 at $120 \mathrm{~km}$ west 342 of the Bassée area in the Chalk aquifer of Paris Basin, has a similar isotopic content as that 343 of the Chalk water sampled at La-Chapelle-sur-Oreuse. River water from the Seine or the 344 Voulzie shows more enriched values. All other samples may be considered to be a mix 345 between "pure" groundwater and surface (rainfall and/or river) water from different periods, 346 and therefore with different isotope contents. Variation of the Seine isotopic composition is 347 about $1 \%$ (Conrad et al., 1978).

348 Some points in the Alluvial (Sa26, Sa38) and Chalk (Sc13, Sc16) aquifers fall on a line with a 349 slope of 4.3 that may correspond to isotopic fractionation caused by evaporation 350 (evaporation lines have a slope between 3.5 and 6 as function of local atmospheric humidity ; 351 Gat, 1981). To test this hypothesis, we calculated the evaporation line with as starting point 352 the average weighted $\delta^{18} \mathrm{O}$ and $\delta^{2} \mathrm{H}$ values of precipitation in Orléans for the period 19993532009 , and which would explain the compositions of samples Sa26, Sa38 (Alluvial aquifer) 354 and Sc13, Sc16 (Chalk aquifer). The calculations show that the two gravel-pit lakes sampled 355 in November 2007 have a stable-isotope composition falling onto the same evaporation line 356 and display the most fractionated isotopic composition from all samples in the Bassée 357 floodplain; here, water renewal is limited and therefore evaporation is expected to be high. 358 Though to a smaller extent, river water is also evaporated and falls on the same evaporation 359 line. This clearly indicates that some sampling points in groundwater integrate evaporated 360 water that could be provided either by gravel-pit lakes or by river water.

\section{5. DISCUSSION}

\section{5.1. Groundwater-river relationships}

363 Existing models (Mégnien, 1979; Armines, 2005), consider that the Chalk aquifer supplies 364 water to the Alluvial aquifer, which then discharges into the Seine. More specific studies 365 (Chabart et al., 1992) have shown that, locally and occasionally, the River Seine can 366 influence the Alluvial aquifer. 
Based on only the major element concentrations, the geochemical composition of groundwater and surface water cannot be discriminated. Other geochemical tools are thus needed to reach a better understanding of the potential relationships between rivers and groundwater.

$\mathrm{Sr}$ isotopes are known (Négrel and Petelet-Giraud, 2005) to be an interesting tool for groundwater-surface water relationships. In the Bassée site the $\mathrm{Sr}$ ratio contrast observed between groundwater and surface water confirms its potential use in this context. The spatial distribution of sampling points in the Bassée floodplain allows the construction of two north-south profiles perpendicular to the Seine. Along these profiles, the $\mathrm{Ca} / \mathrm{Sr}$ ratio and ${ }^{87} \mathrm{Sr} /{ }^{86} \mathrm{Sr}$ values (Fig. 10) show a significant decrease, with the lowest values close to the Seine for the high- and the low-water-stage sampling campaigns. Knowing the $\mathrm{Ca} / \mathrm{Sr}$ ratio and ${ }^{87} \mathrm{Sr} /{ }^{86} \mathrm{Sr}$ values of the Seine water, the concomitant decrease of these two geochemical tracers suggests an increasing contribution of Seine water to the groundwater close to the riverbanks. Furthermore, the $\mathrm{Ca} / \mathrm{Sr}$ ratio (1139) and the $\mathrm{Sr}$ isotopic signature $\left({ }^{87} \mathrm{Sr} /{ }^{86} \mathrm{Sr}=0.70812\right)$ of Chalk aquifer groundwater collected at "La Chapelle", $10 \mathrm{~km}$ away to the north (Fig. 1), are significantly higher than the signatures measured for groundwater collected closed to the Seine (Sa48, Sa41, ScH3, Sa26, Sa21, Sa20 and Sc16). The Ca/Sr ratio and $\mathrm{Sr}$ isotopic compositions thus clearly show a recharge of the aquifers by surface water during the high- and low-water stages. Surface water contribution seems to be of the same importance for both Alluvial and Chalk aquifers. River-water infiltration to groundwater is possible close to the river banks, and around ponds and gravel-pit lakes.

The sampling points located upstream and far from the Seine (Sc22, Sa37, Sc09, Sa61 and Sa65) have the highest $\mathrm{Ca} / \mathrm{Sr}$ ratio (930 to 1134$)$ and ${ }^{87} \mathrm{Sr} /{ }^{86} \mathrm{Sr}(0.70817$ to 0.70835$)$ compared to the Seine water composition. At the opposite, sampling points located downstream of the Bassée alluvial plain and close to the Seine (Sc11, SCH3 and Sa02) have a $\mathrm{Ca} / \mathrm{Sr}$ (876 to 916 ) close to the ratio measured at the upstream Seine station (not all points fall onto the N-S profiles and therefore cannot be seen in Figure 10). Tritium-content data show that very high (>60 TU) values for Sc13, Sa41, Sa48 and Sa61 and high (>15) values for Sc09 indicate a direct influence of river water on the Chalk and Alluvial aquifers at these points. For well Sc13, located far from the main stream but close to a large flooded area, many of the ponds and gravel-pit lakes are most probably fed directly by the River Seine and the canal parallele to the Seine. Tritium content then indicates the input of river water into groundwater via a residence period in ponds and gravel-pit lakes. $A$ quantitative estimation is not possible as tritium input varies throughout the year.

\section{1 \\ 5.2 Relationship between groundwater and gravel-pit lakes}

402 Numerous gravel-pit lakes or natural ponds, swamps, oxbow lakes, and other backwaters

403 exist in the flood plain. Chemical data and ${ }^{87} \mathrm{Sr} /{ }^{86} \mathrm{Sr}$ ratios do not show significant differences 
between water from the aquifers and such surface waters. This was expected, as such waters mostly consist of groundwater.

In these water bodies, water renewal is limited and evaporation is quite high. Evaporation of water before infiltration was highlighted for some wells using the $\delta^{2} \mathrm{H}$ and $\delta^{18} \mathrm{O}$ isotope composition.

Most of the lakes were created by gravel extraction, causing a change in the hydraulic properties of the Alluvial aquifer. It is expected that these artificial holes also facilitate the infiltration of surface water down to the deeper parts of the aquifers. The high permeability of the walls suggests that water will mainly infiltrate horizontally into both the Chalk and Alluvial aquifers.

Water sampled at Sc13 in the Chalk aquifer is the most intensively evaporated. Due to the strong variability in $\mathrm{H}$ and $\mathrm{O}$ isotope signatures of the gravel-pit lakes (only two of them were sampled), it is possible that fractionation is even stronger in other superficial water bodies.

The Sc13 water may result from a mixture of surface water with a more fractionated isotopic signature (higher $\mathrm{H}$ and $\mathrm{O}$ isotopic signatures) than the two gravel-pit lakes sampled in this study or the groundwater. The infiltration of surface water to the aquifer is also clearly shown at sampling points Sa26, Sa38, Sc13 and Sc16 (Fig. 9).

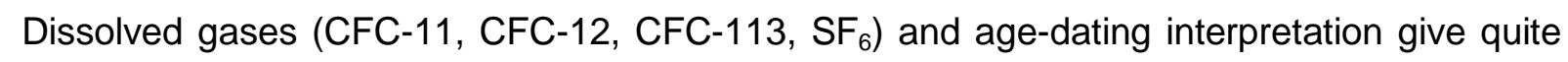
heterogeneous results. Piezometers Sc13 and Sc09 in the Chalk aquifer mainly contain young water, and a direct influence of surface water on these points is thus expected. Being far from the Seine, the influence of ponds or gravel-pit lakes is most likely for these two wells. However, the recharge functioning is quite complex for Sc09 located in the eastern part of the study area, far from the Seine and any flooded area. No explanation could be found to explain the geochemical parameters of groundwater at this point.

\subsection{Impact of the water dynamics on groundwater quality}

An understanding of the hydraulic connections in the Seine floodplain may help in understanding groundwater contamination. Borrow pits were initiated in the area in the 1970s and rapidly increase in number. This extraction activity does not seem to have a direct qualitative impact on the groundwater. Agriculture today occupies $40 \%$ of the Bassée plain as against 46\% in 1976 (Fustec et al., 2001). The dominant crops are cereals (wheat, maize, barley, rape, sunflower) and sugar beets, and diffuse pollution is expected at the study area. Groundwater contamination can be quite high in the left bank of the Seine. Nitrate concentrations measured in June and November 2007 were, for 9 wells of the 19 sampled, over $17 \mathrm{mg} / \mathrm{L}$ and up to $83.1 \mathrm{mg} / \mathrm{L}$ (Sa21), confirming an anthropogenic impact. For 5 wells (4 in the Chalk and 1 in the Alluvial aquifer), reducing conditions may have led to denitrification. Existing data (www.eaufrance.ades.fr) underlines the importance of contamination of the Alluvial aquifer. Actually, $40 \%$ of the wells in the Bassée Alluvial aquifer 
441 in the past showed triazine contamination at least once. Pesticide (mainly atrazine and DEA)

442 and nitrate contamination have also been detected in wells tapping the Chalk aquifer. For the

443 Water Framework Directive, both groundwater bodies (FRHG006 Alluvial aquifer on the

444 Bassée site and FRHG209 Chalk aquifer) were classified as having a poor chemical status.

445 The percentage of young groundwater was compared to nitrate concentrations (Fig. 10). A 446 positive correlation was observed between the percentage of young water and nitrate 447 concentrations for water in aerobic conditions, circulating in the Alluvial and Chalk aquifers. 448 For most sampling points, the more important is the influence of the young groundwater, the 449 higher are the nitrate concentrations (Fig. 11), whereby the "youngest" groundwater dates 450 from 1985 up to 2007. In captive parts of the aquifer or around wetlands, the nitrate 451 concentrations are below the detection limit $(0.5 \mathrm{mg} / \mathrm{L})$, most probably due to denitrification 452 processes (in grey on Fig. 11). Seine water upstream and downstream from the study area 453 has an average nitrate concentration lower than groundwater ( $<0.5 \mathrm{mg} / \mathrm{L}$ to $35.4 \mathrm{mg} / \mathrm{L}$ ).

454 For Sa61, Sa41, Sa48 relatively low nitrate concentrations compared to the apparent CFC 455 ages may be explained by surface water influence (Fig. 11). In fact, the very high tritium 456 content in groundwater from these three wells indicates a stronger influence of the Seine on 457 groundwater, an influence that was also felt in Sc13 and Sc09. At the latter two points, a low 458 redox potential suggests possible denitrification processes. In Sc09, the nitrate concentration 459 in November 2007 (74.2 mg/L) and the redox potential (311 mv NHE) are higher than during 460 the high water period $(<0.5 \mathrm{mg} / \mathrm{L}$ and $345 \mathrm{mV} \mathrm{NHE}$, respectively). As other chemical 461 elements have similar concentrations for the high and low water sampling campaigns, 462 denitrification is the most probable process for explaining major changes for only the $\mathrm{NO}_{3}$ 463 concentration.

464 The two sampled gravel-pit lakes have nitrate concentrations of 2.8 and $<0.5 \mathrm{mg} / \mathrm{L}$. Low 465 nitrate concentrations can be explained by dilution (from rainfall and/or rivers), adsorption by 466 plants and denitrification processes, as was earlier demonstrated in riparian wetlands 467 upstream from the present study area (Bendjoudi et al., 2002). Concentrations of other 468 chemical elements are similar or lower than in river water. Dilution by rainfall input is 469 probably the most important factor, as Redox conditions may not allow denitrification 470 processes and there are no or very few plants in the gravel-pit lakes. Previous work (Fuster 471 et al., 2001) showed that silt deposits at the bottom of the gravel-pit lakes greatly reduce 472 groundwater exchanges. Evaporation and recharge by precipitation therefore are dominating 473 factors of the hydraulic balance of these specific surface-water bodies. Infiltration of water 474 from gravel-pit lakes has a positive influence on groundwater quality. As for river water, the 475 infiltration of water from gravel pits reduces, at least locally, the nitrate concentration in wells 476 upstream from these artificial lakes.

\section{6. CONCLUSIONS}


From the geochemical tools the following conclusions may be drawn:

- No systematic chemical differentiation exists between the Chalk and Alluvial aquifer waters. This confirms that the conceptual hydrogeological model is correct at a regional scale, which considers that Chalk groundwater supplies water to the Alluvial aquifer. However, at the local scale more complex hydraulic connections exist between the different water bodies, as was highlighted by using isotope tools and age-dating. Both the Chalk and the Alluvial aquifers may be influenced by surface water.

- Age-dating highlighted the presence of young, i.e. less than 10 years old, groundwater in the wells Sc09 and Sc13 tapping the Chalk aquifer.

- The influence of Seine water, direct or indirect through the alluvial deposits, was shown using tritium and Sr isotope data for Sa41, Sa48 and Sa61.

- The impact on the aquifer of water stored in the gravel-pit lakes or other natural shallow lakes, ponds or swamps, was highlighted by using stable-isotope tools. The evaporation effect was clear on groundwater collected in wells Sc13, Sc16, Sa26 and Sa38. For Sc13, both a surface-water influence by the Seine through alluvial deposits and by infiltration from gravel-pit lakes is possible.

- $\delta^{2} \mathrm{H}$ and $\delta^{18} \mathrm{O}$, tracers of water-rock interaction processes $\left({ }^{87} \mathrm{Sr} /{ }^{86} \mathrm{Sr}, \mathrm{Ca} / \mathrm{Sr}\right)$ and of water origin $\left({ }^{3} \mathrm{H}\right)$ differentiated the role of the River Seine, gravel-pit lakes (and most probably other superficial water bodies) in local groundwater recharge. The geochemical approach provided a spatial characterization of the origin of water and dissolved elements from surface and groundwater bodies.

- The geochemical approach tested on this site clearly demonstrates the efficiency of geochemical tools for describing the relationships between groundwater, river water and lake water. In addition, it underlined the need of using multiple tools for understanding a complex water system.

- The approach described in this paper can be usefully applied to other case studies, and will help decision makers in the context of natural water management.

\section{Acknowledgements}

We acknowledge funding from IIBRBS, the Seine-Normandie Water Agency, the Interreg project, and BRGM for this research project.

\section{References}

ARMINES, 2005. Etude globale pour l'aménagement de la Bassée. Etude hydrogéologique de faisabilité. Mine Paris. 
Baron, P., Piketti, G., 2001. Plaine Alluvial de la Bassée. Inspection Générale de I'Environnement, Affaire IGE/00/039.

Beard, B.L., Johnson, C.M., Skulan, J.L., Nealson, K.H., Cox, L., Sun, H., 2003. Application of Fe isotopes to tracing the geochemical and biological cycling of Fe. Chem. Geol. 195(1-4), 87-117.

Bendjoudi, H., Weng, P., Guérin, R,. Pastre, J.F., 2002. The riparian wetland of the middle reach of the Seine River: Historical development, reconnaissance and present hydrologic functioning, a case study. J. Hydrol. 263, 131-155.

Bouchaou, L., Michelot, J.L., Qurtobi, M., Zine, N., Gaye, C.B., Aggarwal P.K., Marah, H., Zerouali, A., Taleb, B., Vengosh, A., 2009. Origin and residence time of groundwater in the Tadla basin (Morocco) using multiple isotopic and geochemical tools. J. Hydrol. 379, 323338.

Brenot, A., Baran, N., Petelet-Giraud, E. Négrel, P., 2008. Interaction between different water bodies in a small catchment area in the Paris basin (France): $\mathrm{Sr}$ isotopic tracing of multiple Sr sources. Applied Geochemistry, 23, 58-76.

Cardinal, D., Alleman, L.Y., de Jong, J., Ziegler, K., André, L. 2003. Isotopic composition of silicon measured by multicollector plasma source mass spectrometry in dry plasma mode. J. Anal. Atom. Spectrom. 18, 213-218.

Chabart, M., Lauverjat, J., Mariotti, A., Olive, P., 1992. Étude des caractéristiques hydrochimiques et hydrodynamiques du champ captant de la Grande-Paroisse. Rapport SAGEP-CRECEP-UPMC.

Conrad, G., Jouzel, J., Merlivat, L., Puyoo, S., 1979. La nappe de la craie en HauteNormandie (France) et ses relations avec les eaux superficielles. In: Isotope Hydrology, proceeding of an Internation Symposium on Isotope Hydrology held in Neuherberg in 1978, STI/PUB/493, IAEA, Vienna. pp. 265-287.

Darling, W.G., Gooddy, D.C., Riches, J., Wallis, I., 2010. Using environmental tracers to assess the extent of river-groundwater interaction in a quarried area of the English Chalk. Appl. Geochem. 25, 923-932.

541 Fustec E., Bendjoudi, H., Gaillard, S., Weng, P., Boyer, F., Boet, P., Shannen, O.,

542 Crogennec, S., Billen, G. 2001. Rapport de synthèse 1998-2001. Fonctionnement du territoire 'Bassée'. UMR Sysiphe, UPMC.

Galy, A., Belshaw, N.S., Halicz, L., O'Nions R.K., 2001. High-precision measurement of magnesium isotopes by multiple-collector inductively coupled plasma mass spectrometry. Int. J. Mass Spectrom. 208, 89-98.

547 Gat, J., 1981. Isotopic fractionation. In: Stable Isotope Hydrology - Deuterium and Oxygen-18 in the Water Cycle. (Eds.J. Gat and R. Gonfiantini). Technical Report Series N. 210, IAEA, Viena.

Gooddy, D.C., Darling, W.G., Abesser, C., Lapworth, D.J., 2006. Using chlorofluorocarbons (CFCs) and sulphur hexafluoride (SF6) to characterise groundwater movement and residence time in a lowland Chalk catchment. J. Hydrol. 330, 44-52.

559 IAEA, 2006. Use of Chlorofluorocarbons in Hydrology: A Guidebook. STI/PUB 1238, IAEA, 560 Vienna.

Halicz, L., Galy, A., Belshaw, N.S., O'Nions, R.K., 1999. High-precision measurement of calcium isotopes in carbonates and related materials by multiple-collector inductively coupled plasma mass spectrometry (MC-ICP-MS). J. Anal. Atom. Spectrom. 14, 1835-1838.

Horneman, A., Stute, M., Schlosser, P., Smethie, W., Santella, N., Ho, D.T., Mailloux, B., Gorman, E., Zheng, Y, van Geen, A., 2008. Degradation rates of CFC-11, CFC-12 and CFC113 in anoxic shallow aquifers of Araihazar, Bangladesh. J. Contam. Hydrol. 97, 27-41. 
IAEA/WMO, 2009. Global Network of Isotopes in Precipitation. The GNIP Database. Accessible at: http://isohis.iaea.org.

563 Koepnick R.B., Denison R.E., Burke W.H., Hetherington, E.A., Dahl, D.A., 1990. Construction of the Triassic and Jurassic portion of the Phanerozoic curve of seawater ${ }^{87} \mathrm{Sr} /{ }^{86} \mathrm{Sr}$. Chem. Geol. 80, 327-349.

566 Koepnick, R.B., Burke, W.H., Denison, R.E., Hetherington, E.A., Nelson, H.F., Otto, J.B., 567 Waite, L.E., 1985. Construction of the seawater ${ }^{87} \mathrm{Sr} /{ }^{86} \mathrm{Sr}$ curve for the Cenozoic and 568 Cretaceous: Supporting data. Chem. Geol. 58, 55-81.

569 Lamontagne, S., Leaney, F.W., Herczeg, A.L., 2005. Groundwater-surface water interactions in a large semi-arid floodplain: implications for salinity management. Hydrol. Process. 19, 3063-3080.

Langman, J.B., Ellis, A.S., 2009. A multi-isotope $\left(\delta \mathrm{D}, \delta^{18} \mathrm{O},{ }^{87} \mathrm{Sr} /{ }^{86} \mathrm{Sr}\right.$, and $\left.\delta^{11} \mathrm{~B}\right)$ approach for identifying saltwater intrusion and resolving groundwater evolution along the Western Caprock Escarpment of the Southern High Plains, New Mexico. Appl. Geochem. 25, 159174.

Luais, B., Telouk, P., Albarede, F., 1997. Precise and accurate neodymium isotopic measurements by plasma-source mass spectrometry. Geochim. Cosmochim. Acta 61, 48474854.

Ma, J.Z., Pan, F., Chen, L.H., Edmunds, M., Ding, Z., He, J., Zhou, K., Huang, T., 2010. Isotopic and geochemical evidence of recharge sources and water quality in the Quaternary aquifer beneath Jinchang city, NW China. Appl. Geochem. 25, 996-1007.

Marechal, C.N., Telouk, P., Albarede, F. 1999. Precise analysis of copper and zinc isotopic compositions by plasma-source mass spectrometry. Chem. Geol.156, 251-273.

Mégnien, C. 1965. Possibilités aquifères des alluvions du val de Seine entre Nogent-surSeine et Montereau, incluant Carte géologique et géomorphologique de la Bassée, Rapport BRGM DSGR 65A76.

Mégnien, C., 1979. Hydrogéologie du centre du bassin de paris. Mém. BRGM n98.

Millot, R., Négrel, P., Petelet-Giraud, E., 2007. Multi-isotopic (Li, B, Sr, Nd) approach for geothermal reservoir characterization in the Limagne Basin (Massif Central, France). Appl. Geochem. 22, 2307-2325.

Négrel, P., Pauwels, H., 2004. Interaction between different groundwaters in Brittany catchments (France): Characterizing multiple sources through strontium- and sulphur isotope tracing. Water Air Soil Poll. 151, 261-285.

594 Négrel, P., Petelet-Giraud, E., 2005. Strontium isotopes as tracers of groundwater-induced floods: the Somme case study (France). J. Hydrol. 305, 99-119.

Oster, H., Sonntag, C., Munnich, K.O., 1996. Groundwater age dating with chlorofluorocarbons. Water Resour. Res. 32(10), 2989-3001.

600 Plummer, L.N., Busenberg, E., 2000. Chlorofluorocarbons: Tools for dating and tracing 601 young groundwater. In: P. Cook and A. Herczeg (Eds.), Environmental Tracers in Subsurface 602 Hydrology, Kluwer Academic Publishers, Boston. pp. 441-478.

603 Prinn, R.G., Weiss, R.F., Fraser, P.J., Simmonds, P.G., Cunnold, D.M., Alyea, F.N., 604 O'Doherty, S., Salameh, P., Miller, B.R., Huang, J., Wang, R.H.J., Hartley, D.E., Harth, C., 605 Steele L.P., Sturrock G., Midgley P.M., McCulloch, A., 2000. A history of chemically and 606 radiatively important gases in air deduced from ALE/GAGE/AGAGE. J. Geophys. Res. 105, 607 17751-17792. 
Rehkamper, M., Halliday, A.N., 1999. The precise measurement of T1 isotopic compositions by MC-ICPMS: Application to the analysis of geological materials and meteorites. Geochim. Cosmochim. Acta 63, 935-944.

611 Rouxel, O., Ludden, J., Carignan, J., Marin, L., Fouquet, Y., 2002. Natural variations of Se isotopic composition determined by hydride generation multiple collector inductively coupled plasma mass spectrometry. Geochim. Cosmochim. Acta, 66, 3191-3199.

614 Roy, S., 1996. Utilisation des isotopes du $\mathrm{Pb}$ et du $\mathrm{Sr}$ comme traceurs des apports anthropiques et naturels dans les précipitations et les rivières du Bassin de Paris. PhD Thesis, Univ. Paris 7.

617 Roy, S., Gaillardet, J., Allègre, C.J., 1999. Geochemistry of dissolved and suspended loads of the Seine River, France: anthropogenic impact, carbonate and silicate weathering. 619 Geochim. Cosmochim. Acta 63, 1277-1292.

Sanchez-Cabeza, J.A., Pujol, L., 1999. Study on the hydrodynamics of the Ebro River lower course using tritium as a radiotracer. Water Res. 33, 2345-2356.

Santella, N., David, T.H., Schlosser, P., Stute, M., 2008. Widespread elevated atmospheric SF6 mixing ratios in the Northeastern United States: Implications for groundwater dating. J.Hydrol. 349, 139-146.

Schanen, O., Bendjoudi, H., Levassor, A., Fustec, E., 1998. Quantification des écoulements Nappe-Gravières, en zone alluviale, par optimisation des paramètres du bilan hydrologique. C. R. Acad. Sci. 326, 107-112.

Schultz, T.R., Randall, J.H., Wilson, L.G., Davis S.N., 1976. Tracing sewage effluent recharge - Tucson, Arizona. Groundwater. 14, 463-470.

631 ressources en eau. Juillet 2004.

632 Vengosh, A., Gill, J., Davisson, M.L., Huddon, G.B., 2002. A multi-isotope (B, Sr, O, H, and $633 \mathrm{C})$ and age dating (H-3-He-3 and $\mathrm{C}-14)$ study of groundwater from Salinas Valley, California: 634 Hydrochemistry, dynamics, and contamination processes. Water Resour. Res. 38, 1-17.

635 Vengosh, A., Hening, S., Ganor, J., Mayer, B., Weyhenmeyer, C.E., Bullen, T.D., Paytan, A., 636 2007. New isotopic evidence for the origin of groundwater from the Nubian Sandstone 637 Aquifer in the Negev, Israel. Appl. Geochem. 22, 1052-1073.

638 Vernoux, J.F., Schomburgk, S., Hanot, F., Donsimoni, M., 2004. Projet d'aménagement du 639 site de la Bassée - analyse des travaux de reconnaissance réalisés en 2002-2003, rapport 640 BRGM/RP-52712-FR.

641 Weng, P., Coudrain-Ribsteain, A., Kao, C., Bendjoudi, H., de Marsilly, G., 1999. 642 Demonstration of strong temporary vertical circulation between wetlands and alluvial and 643 regional aquifers. CR. Acad.Sci.. 329, 257-263.

644 Wombacher, F., Rehkamper, M., 2003. Investigation of the mass discrimination of multiple 645 collector ICP-MS using neodymium isotopes and the generalised power law. J. Anal. Atom. 646 Spectrom. 18, 1371-1375. 


\section{$649 \quad$ Figure and table captions}

650 Figure 1 - Map showing the studied area and location of sampling points

651 Figure 2 - N-S synthetic geological profile through the Bassée area

652 Figure 3 - Piper diagram for ground- and surface waters sampled in June and November

6532007 in the Bassée floodplain and in one well upstream in the Chalk aquifer

654 Figure $4-\mathrm{SO}_{4}$ vs. $\mathrm{Cl}$ and $\mathrm{Na}$ vs. $\mathrm{Cl}$ for surface and groundwater sampled in the Bassée plain

655 in June and November 2007 and groundwater sampled upstream (Chalk aquifer)

656 Figure $5-\mathrm{NO}_{3}$ vs. $\mathrm{Cl}$ for surface and groundwater sampled the Bassée plain in June and

657 November 2007 and groundwater sampled upstream (Chalk aquifer)

658 Figure 6 - $\mathrm{Ca}$ vs. Sr and $\mathrm{NO}_{3}$ vs. Sr for surface and groundwater sampled at the Bassée plain

659 in June and November 2007 and groundwater sampled upstream (Chalk aquifer)

660 Figure $7-{ }^{87} \mathrm{Sr} /{ }^{86} \mathrm{Sr}$ vs. $1 / \mathrm{Sr}$ (molar) and ${ }^{87} \mathrm{Sr} /{ }^{86} \mathrm{Sr}$ vs. Ca/ $\mathrm{Sr}$ (molar) for surface and

661 groundwater sampled in the Bassée plain in June and November 2007

662 and in an upstream well

663 Figure 8 - CFC-11 vs. CFC-113 (in pptv) for groundwater collected in the La Bassée site in 664 June and November 2007 and piston flow, exponential and binaxy mixing of young water

665 (recharged in 1985 and 2005) with CFC-free water reference lines

666 Figure $9-\delta^{2} \mathrm{H}$ vs. $\delta^{18} \mathrm{O}$ for surface and groundwater collected in the Bassée site in June and 667 November 2007; local meteoric line and mean weighted values for precipitations at Orléans 668 (1996-2010), mean of Seine water at Poses (1974-1976) and calculated evaporation line

669 Figure $10-{ }^{87} \mathrm{Sr} /{ }^{86} \mathrm{Sr}$ vs. distance and $\mathrm{Sr} / \mathrm{Ca}$ vs. distance for groundwater collected in June

670 and November 2007 along the two north-south profiles

671 Figure $11-\mathrm{NO}_{3}$ vs. \% of young groundwater for groundwater sampled in June and

672 November 2007 in the Bassée alluvial plain

673

674 Table 1 - Analytical results for June and Novembre 2007 sampling campaign 


\begin{tabular}{|c|c|c|c|c|c|c|c|c|c|c|c|c|c|c|c|c|c|c|c|}
\hline $\mathbf{N}^{\circ}$ & type & Date & $\begin{array}{l}\text { Cond. } \\
\mu \mathrm{S} . \mathrm{cm}^{-1}\end{array}$ & $\begin{array}{c}\text { Eh(NHE) } \\
\mathrm{mV}\end{array}$ & $\begin{array}{c}\text { Temp. } \\
{ }^{\circ} \mathrm{C} \\
\end{array}$ & $\mathrm{pH}$ & $\begin{array}{c}\mathrm{Ca} \\
\mu \mathrm{mol} / \mathrm{L}\end{array}$ & $\begin{array}{c}\mathrm{Mg} \\
\mu \mathrm{mol} / \mathrm{L}\end{array}$ & $\begin{array}{c}\mathrm{Na} \\
\mu \mathrm{mol} / \mathrm{L} \\
\end{array}$ & $\begin{array}{c}\mathrm{K} \\
\mu \mathrm{mo} / \mathrm{L} \\
\end{array}$ & $\begin{array}{r}\mathrm{HCO}_{3} \\
\mu \mathrm{mol} / \mathrm{L}\end{array}$ & $\begin{array}{c}\mathrm{Cl} \\
\mu \mathrm{mol} / \mathrm{L}\end{array}$ & $\begin{array}{c}\mathrm{NO}_{3} \\
\mu \mathrm{mol} / \mathrm{L}\end{array}$ & $\begin{array}{c}\mathrm{SO}_{4} \\
\mu \mathrm{mol} / \mathrm{L}\end{array}$ & $\begin{array}{c}\mathrm{Sr} \\
\mu \mathrm{mol} / \mathrm{L}\end{array}$ & $\begin{array}{c}\mathbf{R b} \\
\mu \mathrm{mol} / \mathrm{L} \\
\end{array}$ & ${ }^{87} \mathrm{Sr}{ }^{86} \mathrm{Sr}$ & $\begin{array}{c}\delta^{18} \mathrm{O} \\
\% 0\end{array}$ & $\begin{array}{l}\delta^{2} \mathbf{H} \\
\% \%\end{array}$ \\
\hline \multicolumn{20}{|c|}{ June-07 (high flow period) } \\
\hline Sa02 & Alluvial aquifer & 12/06/2007 & 734 & 383 & 11.9 & 7.1 & 3671 & 86 & 278 & 49 & 4607 & 775 & 969 & 723 & 4.01 & 0.01 & 0.708001 & -6.4 & -42.3 \\
\hline Sa05 & Alluvial aquifer & $12 / 06 / 2007$ & 643 & 359 & 12.3 & 7.1 & 3150 & 136 & 300 & 49 & 4869 & 541 & 658 & 353 & 3.89 & 0.00 & 0.708063 & & \\
\hline Sa16 & Alluvial aquifer & $12 / 06 / 2007$ & 725 & 250 & 12.8 & 7.1 & 3549 & 152 & 513 & 69 & 4902 & 868 & 161 & 931 & 3.40 & 0.01 & 0.708152 & -6.4 & -42.3 \\
\hline Sa20 & Alluvial aquifer & $12 / 06 / 2007$ & 579 & 311 & 12.0 & 7.2 & 2746 & 115 & 413 & 90 & 4721 & 515 & 458 & 214 & 3.38 & 0.02 & 0.707981 & -6.7 & -45.1 \\
\hline Sa21 & Alluvial aquifer & 12/06/2007 & 578 & 350 & 12.5 & 7.4 & 2618 & 66 & 239 & 74 & 3508 & 617 & 1332 & 166 & 2.67 & 0.00 & 0.707940 & -6.4 & -42.5 \\
\hline Sa26 & Alluvial aquifer & 13/06/2007 & 1135 & 173 & 11.7 & 7.0 & 6426 & 222 & 361 & 18 & 5639 & 606 & $<\mathrm{DL}$ & 3650 & 7.51 & 0.00 & 0.707925 & -4.8 & -35.7 \\
\hline Sa37 & Alluvial aquifer & $13 / 06 / 2007$ & 786 & 358 & 11.3 & 7.0 & 3469 & 169 & 983 & 128 & 5459 & 1270 & 540 & 510 & 3.06 & 0.01 & 0.708325 & -6.6 & -43.2 \\
\hline Sa38 & Alluvial aquifer & $13 / 06 / 2007$ & 668 & 154 & 12.0 & 7.0 & 3337 & 123 & 465 & 23 & 5459 & 676 & 94 & 524 & 3.29 & 0.00 & 0.708184 & -4.8 & -35.7 \\
\hline Sa41 & Alluvial aquifer & $13 / 06 / 2007$ & 541 & 351 & 13.2 & 7.2 & 2471 & 152 & 339 & 100 & 4164 & 361 & 276 & 257 & 3.34 & 0.02 & 0.708042 & -6.6 & -45.1 \\
\hline Sa48 & Alluvial aquifer & $13 / 06 / 2007$ & 533 & 302 & 15.9 & 7.3 & 2349 & 160 & 470 & 72 & 4066 & 637 & 95 & 323 & 3.03 & 0.01 & 0.707777 & -6.5 & -44.1 \\
\hline Sa61 & Alluvial aquifer & $12 / 06 / 2007$ & 860 & 287 & 12.1 & 6.9 & 4005 & 387 & 670 & 348 & 7213 & 901 & 202 & 712 & 3.77 & 0.00 & 0.708168 & -6.8 & -44.0 \\
\hline Sa65 & Alluvial aquifer & $13 / 06 / 2007$ & 763 & 375 & 17.3 & 7.1 & 3436 & 140 & 465 & 51 & 5049 & 989 & 989 & 339 & 3.56 & 0.00 & 0.708246 & -6.4 & -42.4 \\
\hline Sc09 & Chalk aquifer & $13 / 06 / 2007$ & 645 & 345 & 18.6 & 7.2 & 2885 & 128 & 474 & 0 & 4213 & 769 & $<\mathrm{DL}$ & 258 & 3.07 & 0.01 & 0.708168 & -7 & -46.9 \\
\hline Sc11 & Chalk aquifer & $12 / 06 / 2007$ & 525 & 386 & 12.3 & 7.2 & 2731 & 78 & 487 & 28 & 4557 & 538 & 432 & 232 & 3.09 & 0.00 & 0.708119 & -6.9 & -45.9 \\
\hline Sc13 & Chalk aquifer & $12 / 06 / 2007$ & 414 & 105 & 13.4 & 7.4 & 1788 & 111 & 313 & 38 & 3656 & 437 & $<D L$ & 22 & 2.47 & 0.00 & 0.707807 & -2.4 & -25.2 \\
\hline Sc16 & Chalk aquifer & $13 / 06 / 2007$ & 682 & 175 & 11.5 & 7.0 & 3479 & 189 & 330 & 31 & 5705 & 462 & $<\mathrm{DL}$ & 715 & 3.81 & 0.01 & 0.708063 & -6 & -41.8 \\
\hline Sc22 & Chalk aquifer & $12 / 06 / 2007$ & 700 & 321 & 12.5 & 7.0 & 3519 & 103 & 452 & 15 & 5443 & 854 & $<D L$ & 352 & 2.81 & 0.00 & 0.708582 & -6.7 & -44.5 \\
\hline $\mathrm{ScH} 3$ & Chalk aquifer & $12 / 06 / 2007$ & 500 & 282 & 14.7 & 7.3 & 2259 & 144 & 270 & 41 & 3787 & 352 & 626 & 163 & 2.82 & 0.00 & 0.707798 & -6.8 & -46.0 \\
\hline $\mathrm{ScH} 4$ & Chalk aquifer & $13 / 06 / 2007$ & 733 & 162 & 11.8 & 6.9 & 3451 & 193 & 643 & 33 & 5721 & 814 & $<\mathrm{DL}$ & 594 & 3.39 & 0.00 & 0.708156 & -6.8 & -45.1 \\
\hline Seine Amont & River & $13 / 06 / 2007$ & 536 & 344 & 23.5 & 8.2 & 2334 & 165 & 591 & 66 & 3607 & 732 & 361 & 426 & 3.25 & 0.02 & 0.707728 & -6.3 & -43.6 \\
\hline Voulzie & River & $13 / 06 / 2007$ & 661 & 364 & 18.7 & 8.2 & 2339 & 165 & 535 & 64 & 3689 & 718 & 368 & 425 & 2.24 & 0.00 & 0.708282 & -6.6 & -44.0 \\
\hline Seine Aval & River & $13 / 06 / 2007$ & 538 & 391 & 23.1 & 8.2 & 3027 & 210 & 604 & 79 & 4836 & 941 & 600 & 363 & 3.14 & 0.00 & 0.707749 & -6.2 & -42.0 \\
\hline \multicolumn{20}{|c|}{ October-07 (low flow period) } \\
\hline $\mathrm{Sa} 02$ & Alluvial aquifer & 0 & 73 & 271 & 12.9 & 7. & 3641 & 74 & 243 & 49 & 70 & 868 & 985 & 783 & 4.16 & 1 & 019 & -6.5 & -41.3 \\
\hline Sa05 & Alluvial aquifer & 06/11/2007 & 640 & 265 & 13.5 & 7.3 & 3137 & 115 & 257 & 51 & 5016 & 552 & 650 & 354 & 3.89 & 1 & 0.708108 & -6.7 & -42.8 \\
\hline Sa16 & Alluvial aquifer & $06 / 11 / 2007$ & 735 & 243 & 13.5 & 7.2 & 3456 & 160 & 296 & 28 & 5574 & 501 & $<\mathrm{DL}$ & 760 & 4.16 & 1 & 0.708242 & -6.3 & -41.5 \\
\hline Sa20 & Alluvial aquifer & $06 / 11 / 2007$ & 563 & 378 & 12.8 & 7.5 & 2626 & 95 & 343 & 90 & 4656 & 510 & 571 & 177 & 3.32 & 1 & 0.708002 & -6.9 & -45.7 \\
\hline Sa21 & Alluvial aquifer & $06 / 11 / 2007$ & 575 & 301 & 14.2 & 7.6 & 2656 & 58 & 200 & 64 & 3459 & 668 & 1340 & 166 & 2.72 & 1 & 0.707974 & -6.4 & -42.3 \\
\hline Sa26 & Alluvial aquifer & $06 / 11 / 2007$ & 1095 & 139 & 13.2 & 7.2 & 6095 & 189 & 335 & 18 & 5410 & 631 & $<\mathrm{DL}$ & 3373 & 7.19 & 1 & 0.707964 & -4.7 & -34.2 \\
\hline Sa37 & Alluvial aquifer & $06 / 11 / 2007$ & 818 & 302 & 13.5 & 7.4 & 3651 & 156 & 961 & 125 & 5705 & 1693 & 518 & 534 & 3.31 & 1 & 0.708349 & -6.6 & -42.5 \\
\hline Sа38 & Alluvial aquifer & $07 / 11 / 2007$ & 661 & 196 & 12.9 & 7.1 & 3257 & 119 & 430 & 28 & 5393 & 735 & $<\mathrm{DL}$ & 519 & 3.20 & 1 & 0.708231 & -4.3 & -34.3 \\
\hline Sa41 & Alluvial aquifer & $07 / 11 / 2007$ & 593 & 330 & 14.2 & 7.3 & 2698 & 148 & 330 & 113 & 4803 & 400 & 353 & 404 & 3.73 & 1 & 0.708066 & -6.9 & -45.6 \\
\hline Sa48 & Alluvial aquifer & $07 / 11 / 2007$ & 425 & 276 & 15.6 & 7.5 & 1900 & 119 & 287 & 51 & & 414 & 13 & 243 & 2.52 & 1 & 0.707802 & -6.3 & -43.0 \\
\hline Sa61 & Alluvial aquifer & $06 / 11 / 2007$ & 841 & 306 & 13.2 & 7.1 & 3868 & 296 & 587 & 315 & 6951 & 1090 & 192 & 575 & 3.55 & 1 & 0.708195 & -6.8 & -44.5 \\
\hline Sa65 & Alluvial aquifer & $07 / 11 / 2007$ & 678 & 325 & 12.8 & 7.4 & 3057 & 119 & 504 & 64 & 4459 & 1096 & 1129 & 177 & 3.28 & 1 & 0.708244 & -6.6 & -44.5 \\
\hline Sc09 & Chalk aquifer & $07 / 11 / 2007$ & 614 & 311 & 12.5 & 7.5 & 2890 & 107 & 422 & 0 & 4033 & 893 & 1197 & 212 & 3.11 & 1 & 0.708177 & -7.0 & -46.6 \\
\hline Sc11 & Chalk aquifer & 06/11/2007 & 565 & 282 & 12.0 & 7.2 & 2678 & 70 & 387 & 31 & 4672 & 603 & 484 & 217 & 3.05 & I & 0.708127 & -6.9 & -46.2 \\
\hline Sc13 & Chalk aquifer & 06/11/2007 & 41 & 88 & 14.9 & 7.6 & 1798 & 103 & 300 & 38 & 3885 & 462 & $<\mathrm{DL}$ & 21 & 2.49 & 1 & 0.707820 & -2.4 & -24.7 \\
\hline Sc16 & Chalk aquifer & 06/11/2007 & 679 & 146 & 12.7 & 7.3 & 3579 & 148 & 413 & 51 & 5180 & 910 & 519 & 809 & 3.37 & 1 & 0.708015 & -6.2 & -41.5 \\
\hline Sc22 & Chalk aquifer & 06/11/2007 & 645 & 283 & 12.2 & 7.3 & 3252 & 78 & 370 & 18 & 5410 & 701 & 340 & 259 & 2.81 & 1 & 0.708476 & -6.9 & -44.8 \\
\hline $\mathrm{ScH} 3$ & Chalk aquifer & 07/11/2007 & 509 & 378 & 12.8 & 7.3 & 2292 & 128 & 239 & 41 & 3770 & 383 & 653 & 166 & 2.79 & 1 & 0.707837 & -6.8 & -45.5 \\
\hline $\mathrm{ScH} 4$ & Chalk aquifer & 06/11/2007 & 740 & 149 & 12.2 & 7.3 & 3514 & 165 & 604 & 33 & 5836 & 966 & $<D L$ & 687 & 3.08 & 1 & 0.708259 & -6.9 & -45.8 \\
\hline Seine Upstream & River & $07 / 11 / 2007$ & 45 & 33 & 10.1 & 8.3 & 19 & 14 & 322 & 54 & 3443 & 456 & 224 & 257 & 2.69 & 1 & 0.707783 & -6.1 & -42.4 \\
\hline Voulzie & Riv & 07/11/2007 & 67 & 329 & 8.7 & 8. & 2868 & 18 & 600 & 100 & 4 & 1082 & 571 & 315 & 2.31 & 1 & 0.708247 & -6.6 & -43.9 \\
\hline Seine Dowstream & Riv & $07 / 11 / 2007$ & 44 & 341 & 10.5 & 8.4 & 1925 & 140 & 309 & 54 & 3295 & 451 & 219 & 250 & 2.61 & 1 & 0.707790 & -6.1 & -41.9 \\
\hline Bassin Amont & Ponds & $07 / 11 / 2007$ & 287 & 320 & 9.1 & 8.0 & 1012 & 119 & 322 & 64 & 1754 & 459 & 45 & 190 & 2.39 & 1 & 0.707933 & -4.9 & -35.8 \\
\hline Bassin Aval & Ponds & $07 / 11 / 2007$ & 346 & 348 & 10.2 & 8.2 & 1384 & 123 & 339 & 43 & 2787 & 558 & $<\mathrm{DL}$ & 63 & 2.32 & 1 & 0.707816 & -3.7 & -31.2 \\
\hline AEP La Chapelle & Chalk aquifer & $07 / 11 / 2007$ & 522 & 387 & 12.0 & 7.3 & 2379 & 62 & 274 & 77 & 3820 & 454 & 811 & 97 & 2.09 & 1 & 0.708119 & -7.1 & -46.5 \\
\hline \multicolumn{20}{|c|}{ Sampling of the Seine River at Bray/Seine on a monthly basis } \\
\hline Seine at Bray/Seine & River & $13 / 06 / 2007$ & 536 & 344 & 23.5 & 8. & 23 & 165 & 59 & 66 & 36 & 73 & 36 & 426 & 3.2 & 1 & I & 1 & 1 \\
\hline Seine at Bray/Seine & River & 03/08/2007 & 402 & & 20.9 & 8.2 & 1910 & 144 & 300 & 43 & 3180 & 355 & 240 & 242 & 2.23 & 1 & 1 & 1 & 1 \\
\hline Seine at & River & $21 / 09 / 2007$ & 386 & 458 & 16.2 & 8.3 & 1796 & 144 & 322 & 46 & 3098 & $3 s$ & 227 & 214 & 2.23 & I & 1 & I & 1 \\
\hline & Rive & & 45 & 33 & 10.1 & 8. & 198 & 14 & 322 & 54 & & At 1 & 224 & 257 & 2 & 1 & 1 & 1 & 1 \\
\hline Seine at Bray/Seine & River & 04 & $54 \varepsilon$ & 59 & 6.1 & 8.3 & 267 & 15 & 326 & 54 & 42 & $4 \varsigma$ & 458 & 294 & 3.26 & 1 & 1 & 1 & 1 \\
\hline Seine at Bray/Seine & River & $15 / 02 / 2008$ & 545 & 617 & 6.5 & 8.4 & 2676 & 148 & 330 & 49 & 4197 & 544 & 463 & 286 & 3.17 & 1 & 1 & 1 & 1 \\
\hline Seine at Bray/Seine & River & $25 / 03 / 2008$ & 492 & 549 & 7.2 & 8.2 & 2377 & 136 & 235 & 49 & 4328 & 327 & 397 & 183 & 2.66 & 1 & 1 & 1 & 1 \\
\hline Seine at Bra & River & $30 / 04 / 2008$ & 509 & 573 & 13.3 & 8.1 & 2387 & 13 & 23 & 38 & 4246 & 456 & 329 & 206 & 3.56 & 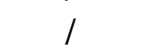 & I & 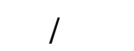 & \\
\hline Seine at Bray/Seine & |River & 27/05/2008 & 506 & & 16.7 & 8.1 & 2444 & 144 & 378 & 51 & 3967 & 580 & 405 & 279 & 3.92 & 1 & 1 & 1 & 1 \\
\hline
\end{tabular}




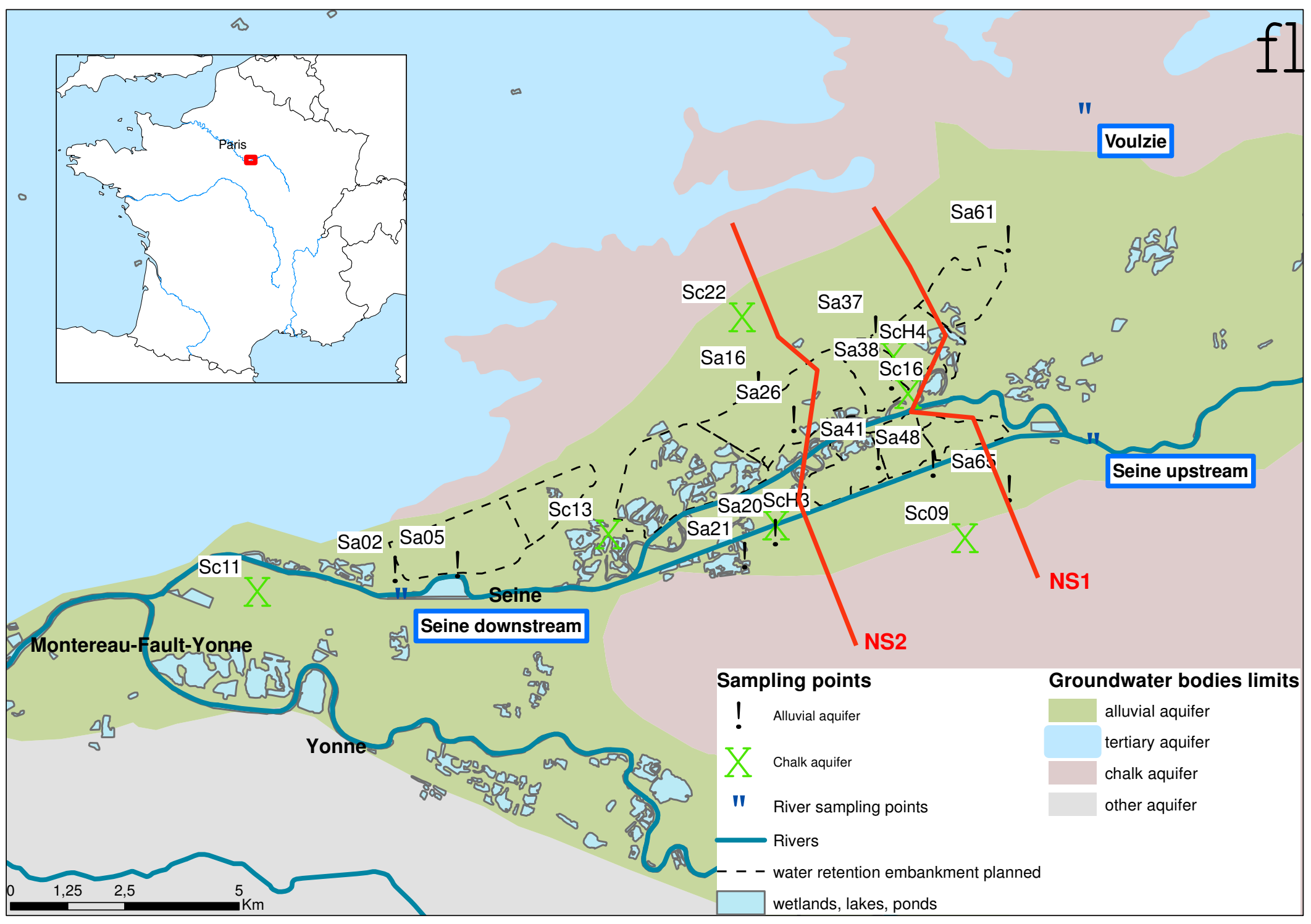




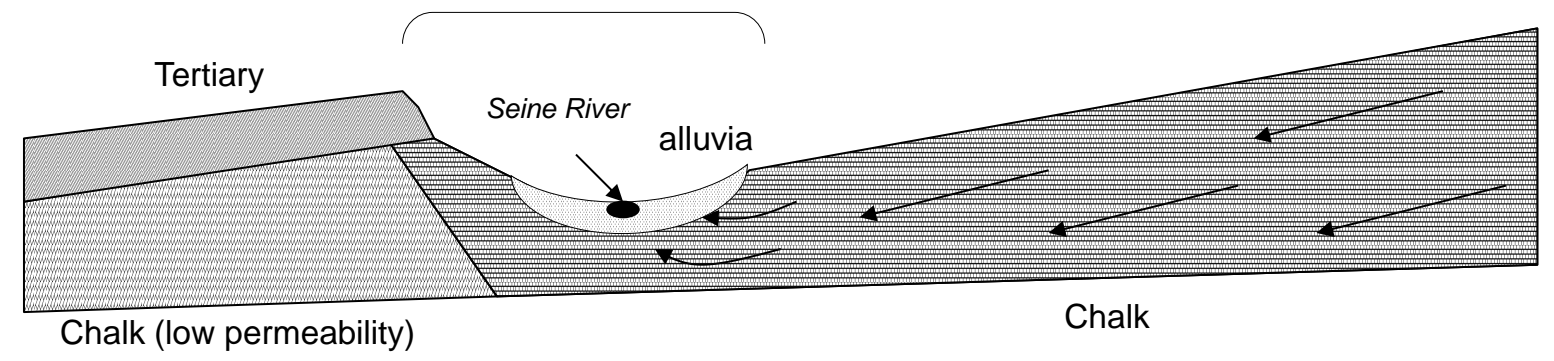

Figure 2 : Synthetic geological profile of the La Bassée area 


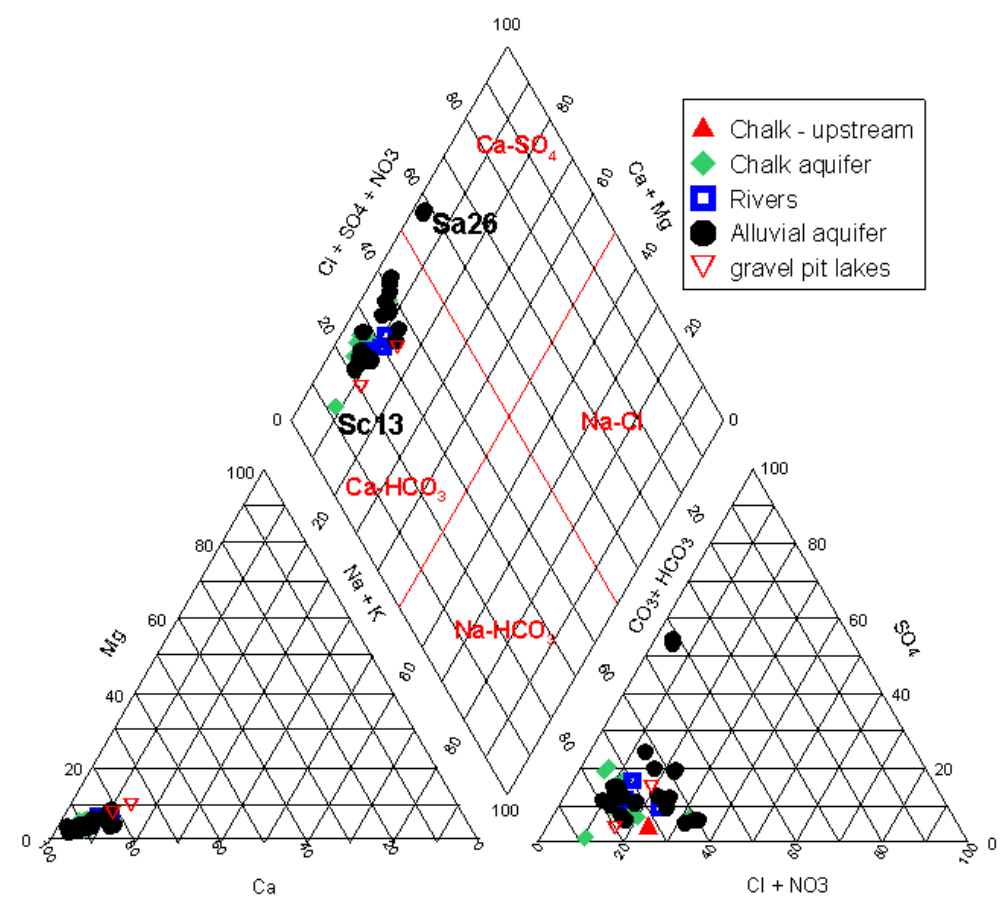

Figure 3 : Piper diagram for ground and surface water sampled in June and November 2007 in the La Bassée floodplain and one well groundwater upstream (chalk aquifer) 

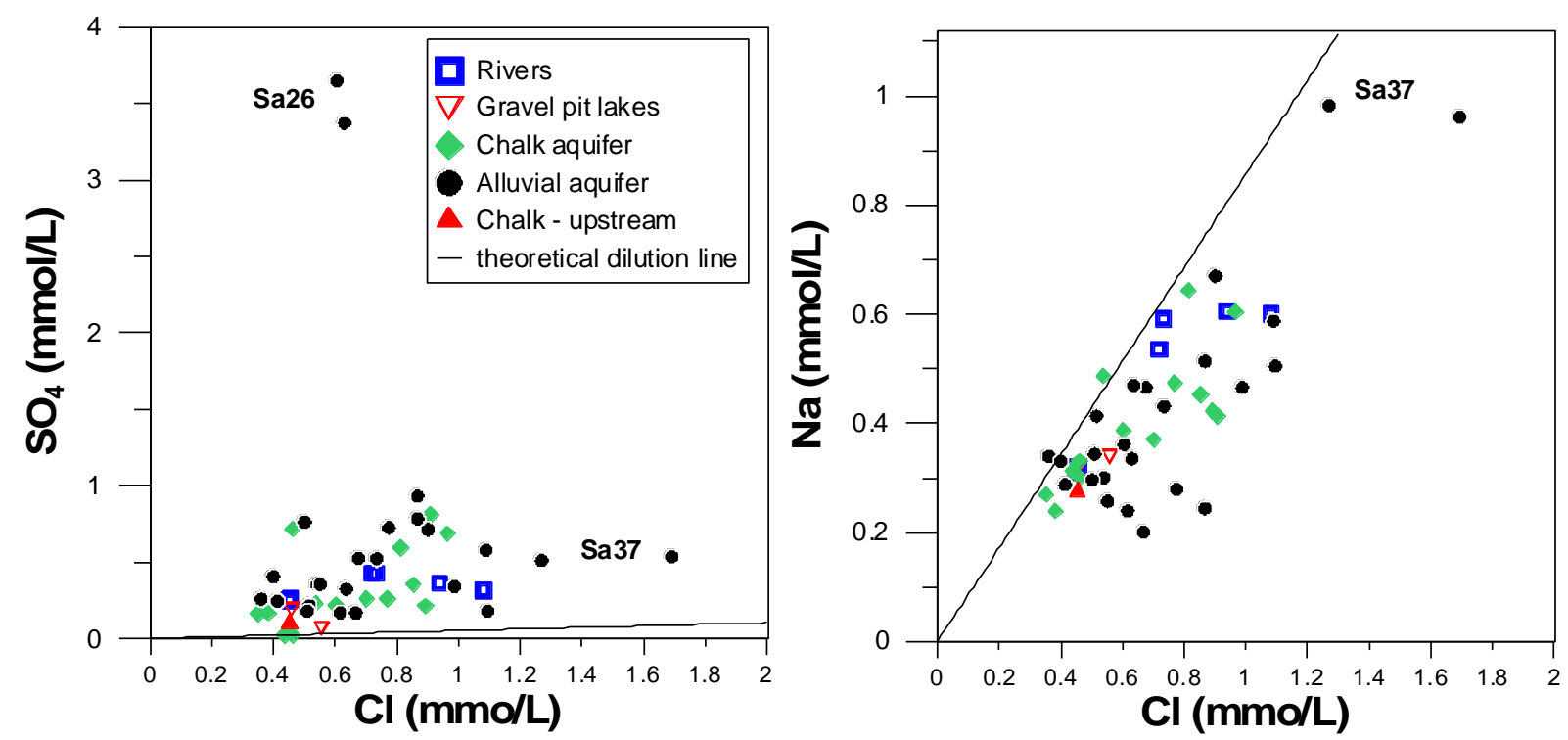

Figure $4: \mathrm{SO}_{4}$ vs. $\mathrm{Cl}$ and $\mathrm{Na}$ vs. $\mathrm{Cl}$ for surface and groundwater sampled the La Bassée plain in June and November 2007 and groundwater sampled upstream (Chalk aquifer) 


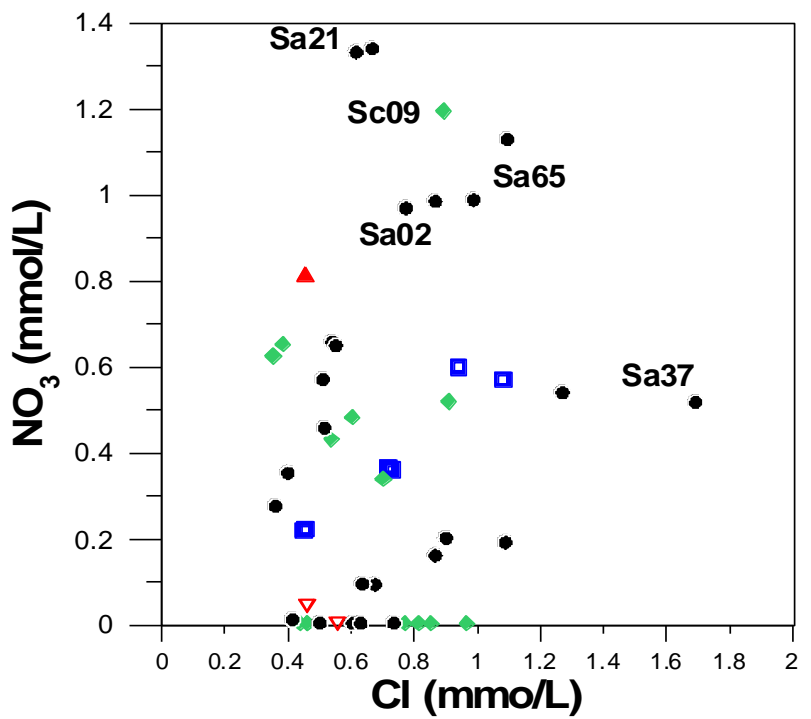

Figure $5: \mathrm{NO}_{3}$ vs. $\mathrm{Cl}$ for surface and groundwater sampled at the La Bassée plain in June and November 2007 and groundwater sampled upstream (chalk Aquifer) 

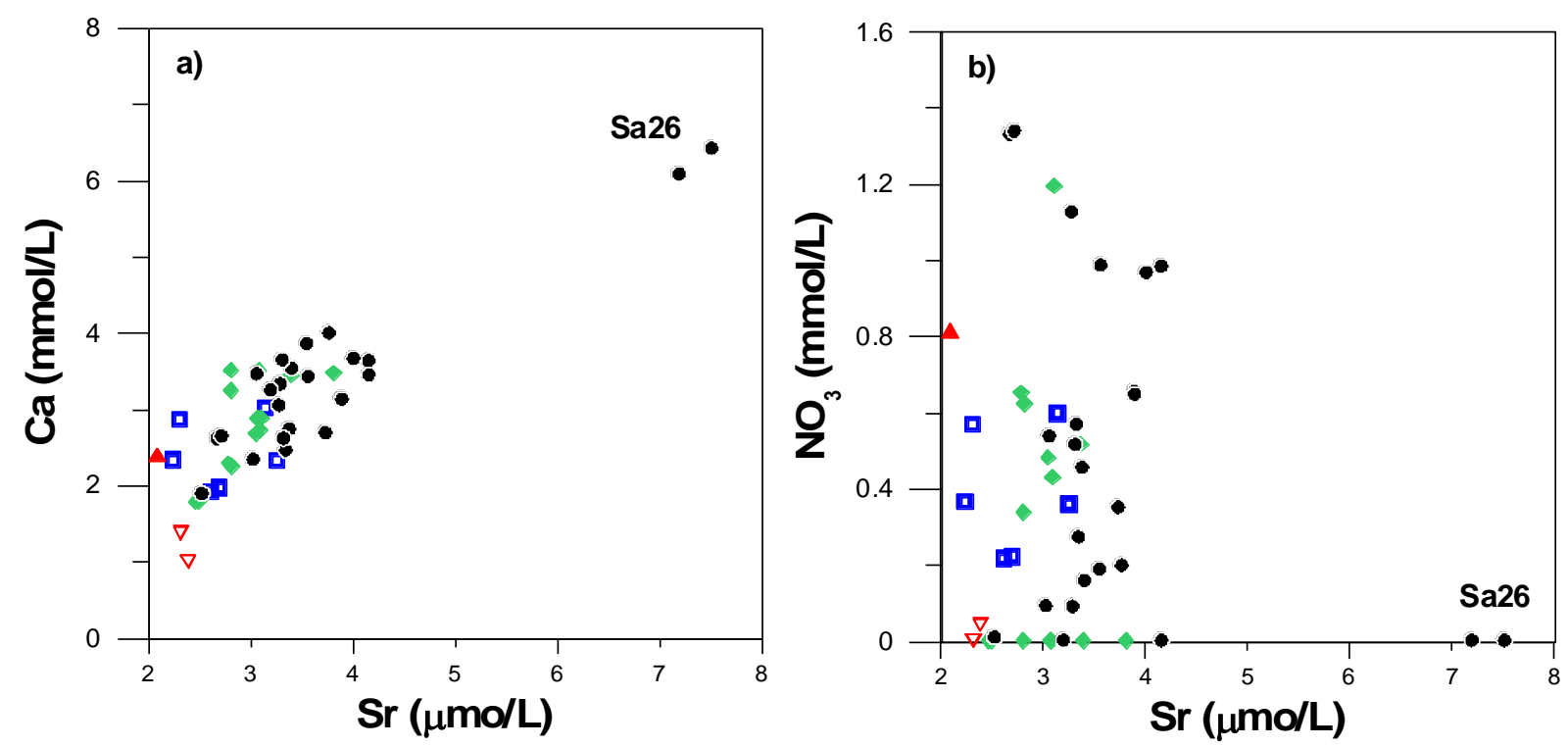

Figure 6 : Ca vs. $\mathrm{Sr}$ and $\mathrm{NO}_{3}$ vs. Sr for surface and groundwater sampled at the La Bassée plain in June and November 2007 and groundwater sampled upstream (Chalk aquifer) 

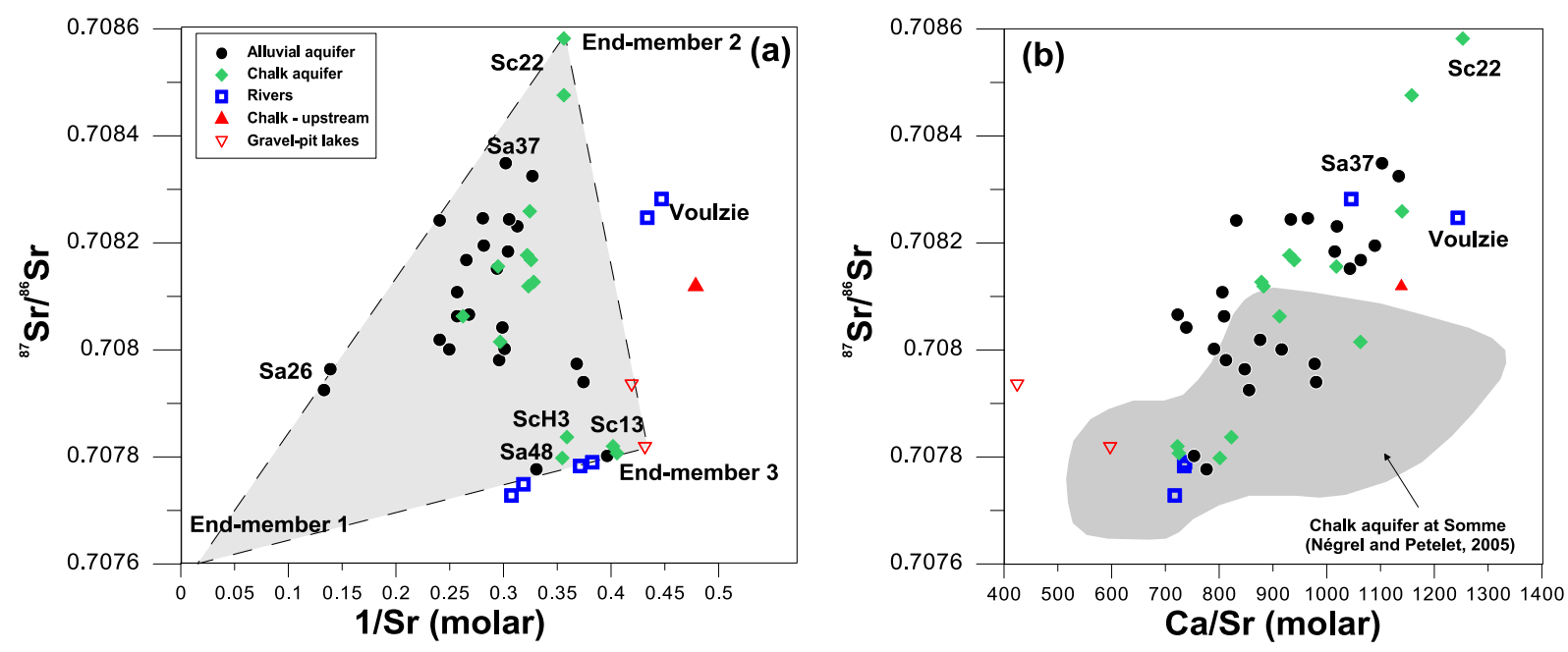

Figure $7:{ }^{87} \mathrm{Sr} /{ }^{86} \mathrm{Sr}$ vs. $1 / \mathrm{Sr}$ (molar) and ${ }^{87} \mathrm{Sr} /{ }^{86} \mathrm{Sr}$ vs. $\mathrm{Ca} / \mathrm{Sr}$ (molar) for surface and groundwater sampled at La Bassée plain in June and Novembre 2007 and one upstream well 


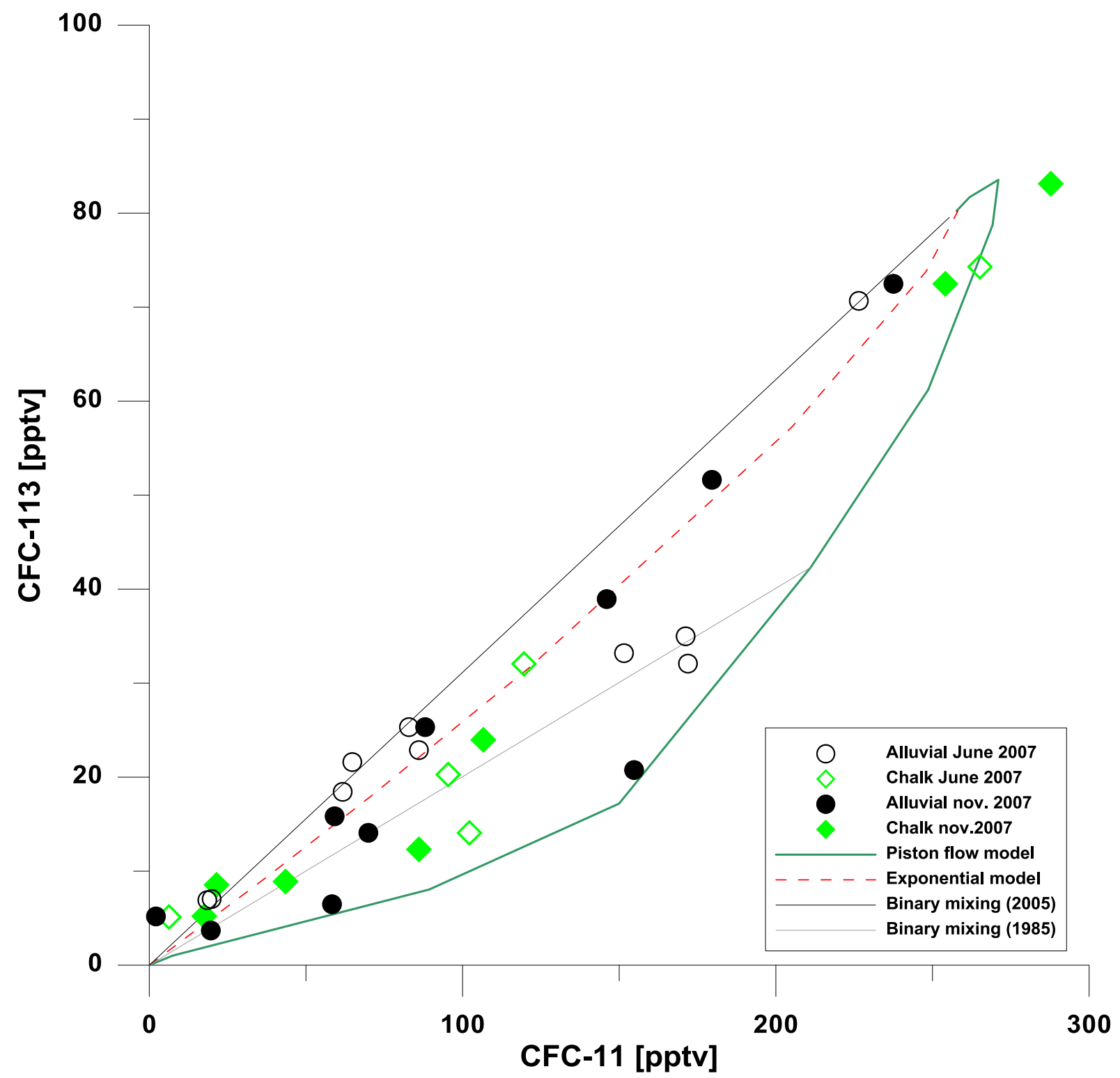

Figure 8 : CFC-11 vs. CFC-113 (in pptv) for groundwater collected in the La Bassée site in June and November 2007 and piston flow, exponential and binaxy mixing of young water (recharged in 1985 and 2005) with CFC-free water reference lines 


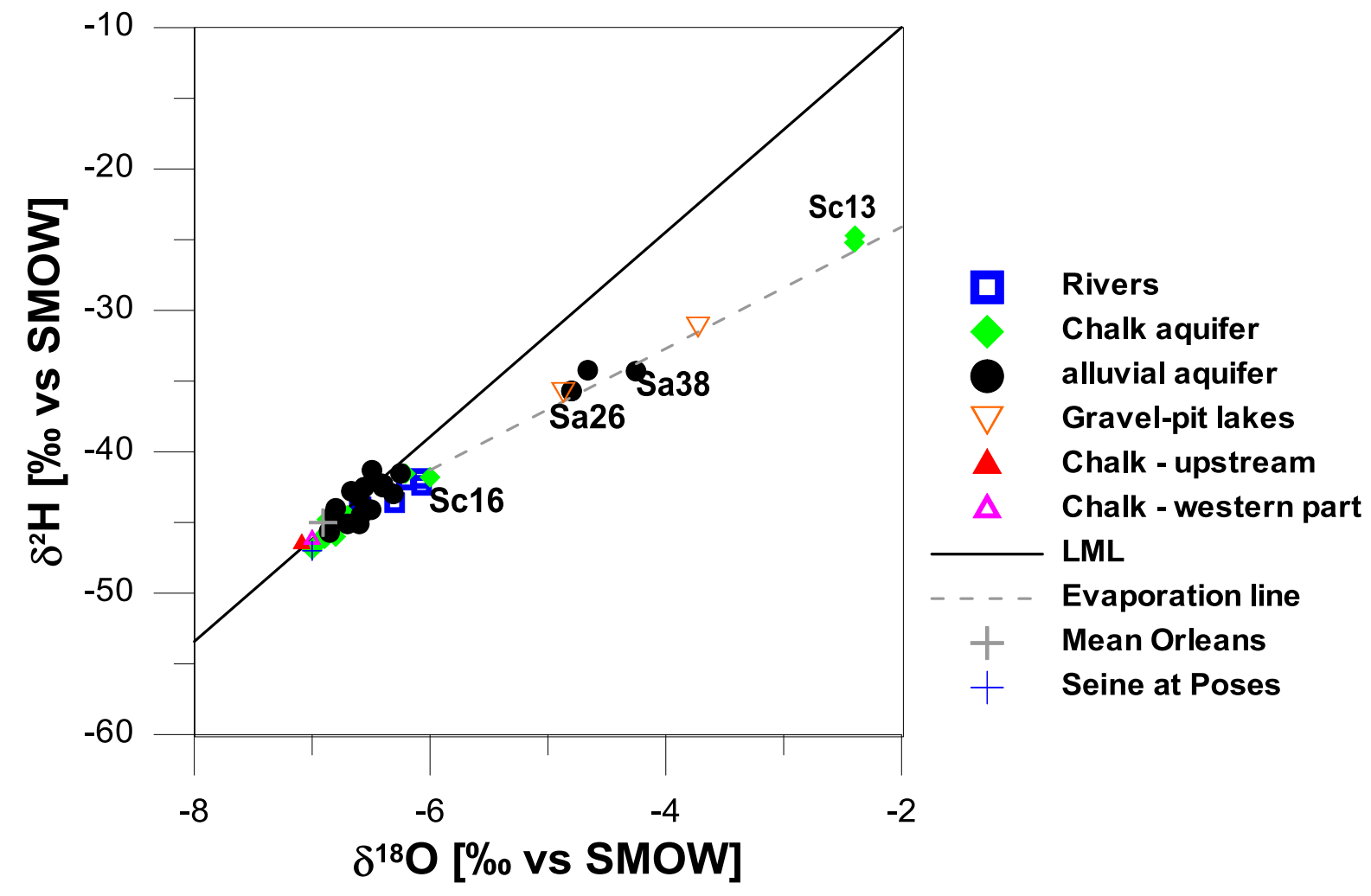

Figure $9: \delta^{2} \mathrm{H}$ vs $\delta^{18} \mathrm{O}$ for surface and groundwater collected in the La Bassée site in June and November 2007; local meteoric line and mean weighted values for precipitations at Orléans (1996-2010), mean of Seine water at Poses (1974-1976) and calculated evaporation line 

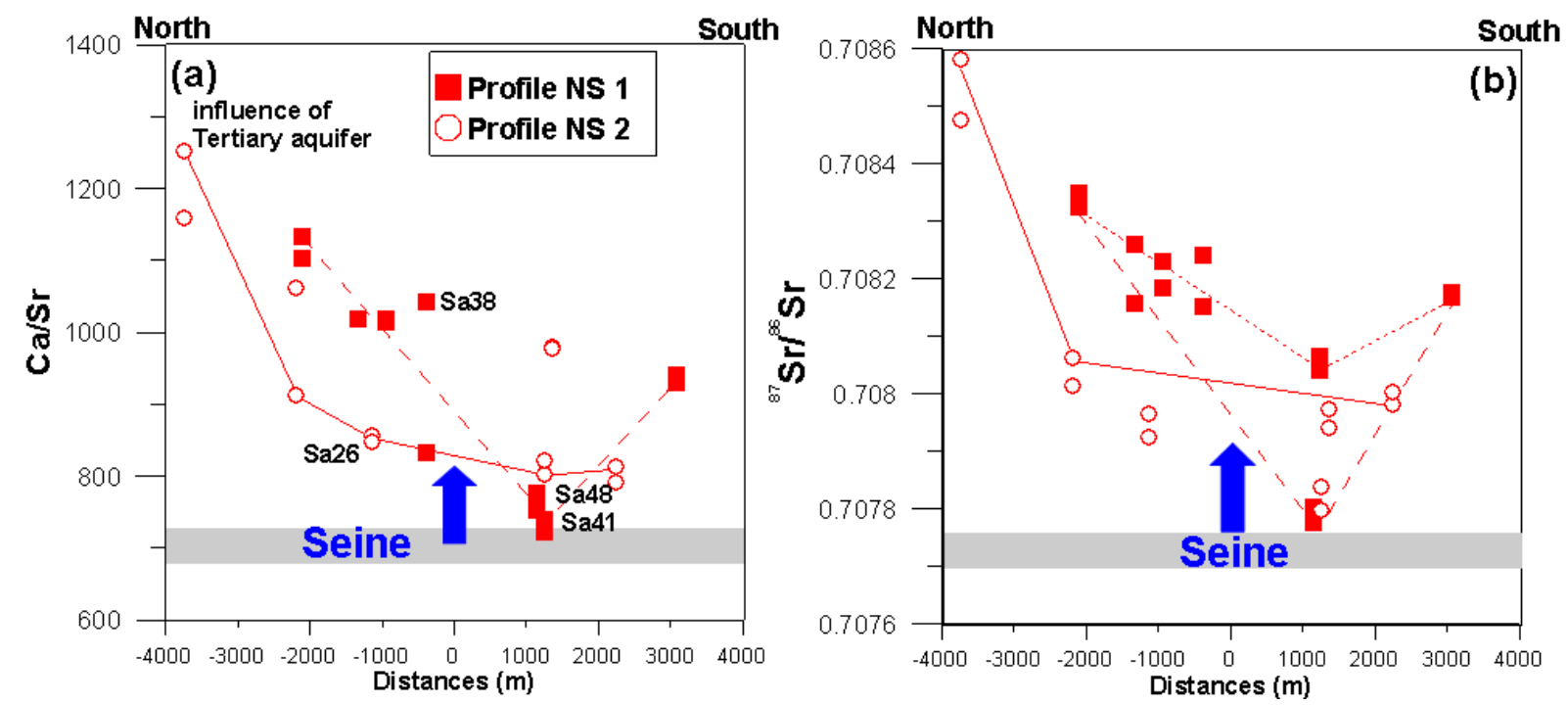

Figure 10: ${ }^{87} \mathrm{Sr} /{ }^{86} \mathrm{Sr}$ vs. distance and $\mathrm{Sr} / \mathrm{Ca}$ vs. distance for the groundwater collected in June and November 2007 following the two North-South profiles 


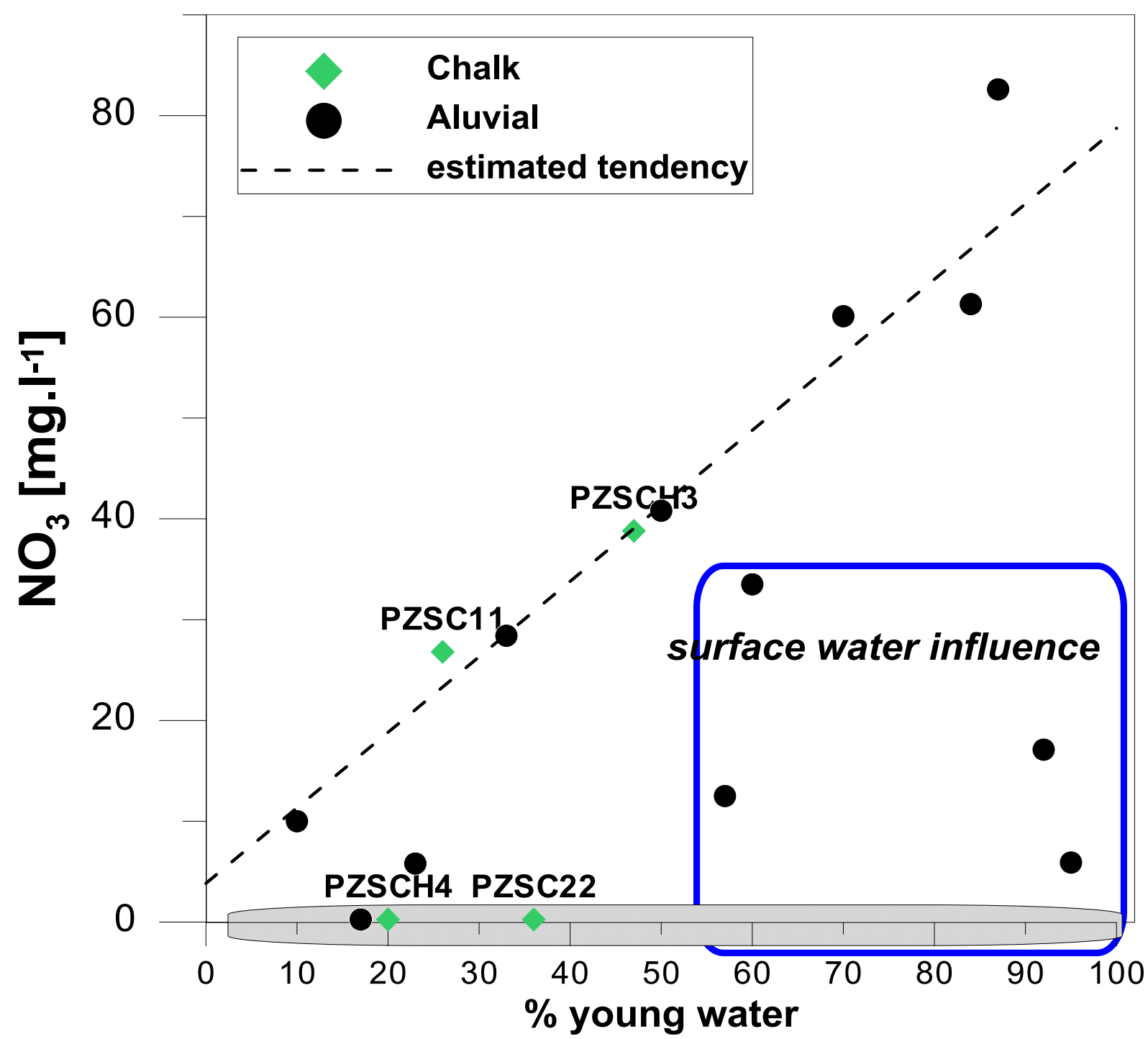

Figure 11: $\mathrm{NO}_{3}$ vs. \% of young groundwater for groundwater sampled in June and November 2007 in the La Bassée alluvial plain 